University of Louisville

ThinkIR: The University of Louisville's Institutional Repository

Electronic Theses and Dissertations

1939

\title{
Ethyl cellulose modified exterior house paints.
}

Hugo Louis Schaefer
University of Louisville

Follow this and additional works at: https://ir.library.louisville.edu/etd

Part of the Chemical Engineering Commons

\section{Recommended Citation}

Schaefer, Hugo Louis, "Ethyl cellulose modified exterior house paints." (1939). Electronic Theses and Dissertations. Paper 1902.

https://doi.org/10.18297/etd/1902

This Master's Thesis is brought to you for free and open access by ThinkIR: The University of Louisville's Institutional Repository. It has been accepted for inclusion in Electronic Theses and Dissertations by an authorized administrator of ThinkIR: The University of Louisville's Institutional Repository. This title appears here courtesy of the author, who has retained all other copyrights. For more information, please contact thinkir@louisville.edu. 


\title{
s. \\ Axt
}

THE UNIVERSITY OF LOUISVILIE

ETHYL CELUULOSE MODIPISD

EXTERIOR HOUSE PAINTS

\author{
A Thesis \\ Submitted to the raculty \\ of the Graduate School \\ in Partial Fuifillmont of the \\ Requirements for the Degree of
}

MASTER OF

CERMICAL ENGINEERING

Department of Chemical Engineoring

By

Hugo Louls Scheefor Jr.

1939 
ETHYL CELLULOSE MODIFIED

EXTERIOR HOUSE PAINTS

Approved by Sxamining Committee:

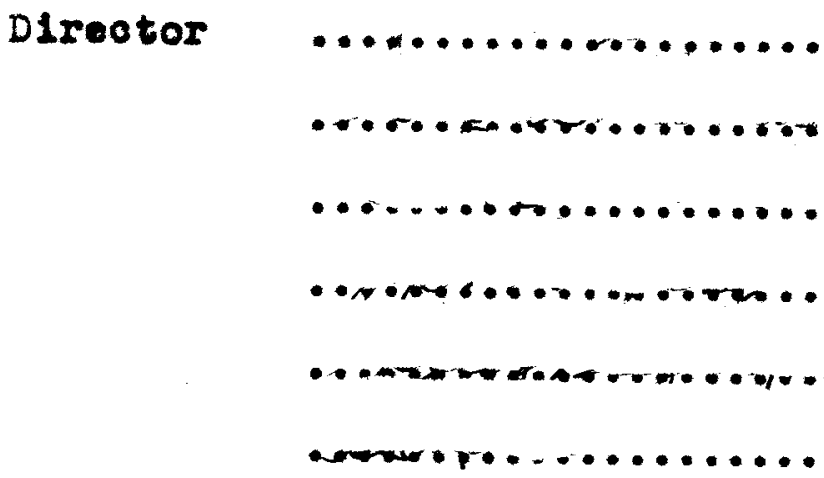

Approved for engl1ah:

$\omega \bullet \cdots \cdots \cdots \ldots \ldots \ldots \ldots \ldots \ldots+\cdots$

June 6,1939 
TABLE OF CONTENTS

Page

LIST OF TABLES

$\checkmark$

LIST OF ILLUSTRATIONS v11

ACRNOVLEDGSMENT

INTRODUCTION 1

HISTORICAL 4

THEORETICAI 7

RAW MATERIAIS 18

GENERAL PROCEDURE 23

Part I - Hiding Power 36

Theoretioal 37

Experimentel Work 39

Conclustons 42

Part II - Gloss 43

Theoretical 44

Experimental York 45

Conclusions 48

Part III - Penetration 49

Theoretioal 50

Experimental Work 51

Conclusions 53

Part IV - Brushability 54

Theoretical 55

Exporimental tork 56

Conclusions 59 
Part V - Loreling 60

Theoretion 61

Experimental Fork 62

Conclusions e5

Part VI - Sagging 68

Theoretical 67

Experimentel rork 68

Conclusions 71

Part VII - Herdness or Trok 72

Thooretionl 73

Experimental Work 75

Conclusions 78

Pert VIII - Abrasion Resistance 79

Theoretioal 80

Experlmontal Hork 81

Oonclusions 84

$\begin{array}{ll}\text { Part IX - Weatherabllity } & 85\end{array}$

Theoretioal 86

Experimental kork 88

SUDBAARY 93

ACKNOYLEDGMENS 96

BIBLIOGRAPEY $\quad 98$ 
LIST OF TABLES

Tablo

Page

I Sumerery of 011 Cooks Prepered 26

II Sumery of Plgment Formulations 28

III Summary of 0128 used in Exterior Paints 33

IV Sumary of Primer Formulations Prepared

for Testing

34

V Summary of Topoout Formulatlone Prepared

for Testins 35

VI Hlalng Power or Exterlor Eouse Primers 40

VII HIdIng powar of Bxterlor House Topconts 41

VII Gloss or Exterior House Primers 46

IX 01088 of Exterlor House Fopcouts 47

$X$ Penetretion of Bxterior House Priners 52

XI Brushabillty of Exterlor House Primers 57

XII Brueheb111ty of Exterlor Louse Fopeosts 58

XIII leveling of latsintor House Primers 63

XIV Leveling of sxterior House Topcos:s 64

XV Sagging of Exterior House Frimers 69

XVI Sageine of sxterior Louse Topooats 70

XVII Hardness or Tack of kxterlor House Primers 76

XVIII Hardness or Tack of Bxterfor Fouse Fopeosts 77

XIX Abrasion Res1stance or Bxterlor House 


\section{LIST OF TABLES \\ CONTINUED}

Tablo

Page

XX Abrasion Resistance of Exterior House

Topcoats

83

XXI Summary of Panels Frepared for feathering

89 
LIST OF ILLUSTRATIONS

Flgure

Page

1 Stainless 3teol Cooker

25

2 Rolier-Typo Paint Hill

30

3 Stormer Viscosimeter

31

4 Swerd Hardness Rocker

74

5 Paint Fence

92 
ACKNO VLLDGELRNT

\author{
The \\ Author W1shes \\ to Acknowledge his \\ fpprociation for the \\ KInd and Valuablo Assistance \\ Given by \\ Dr. R.C. Ernst \\ Who Directed \\ this
}

Research 
1.

INTRODUCTION 
The purpose of this investigation was to show the effects of the introduction of ethyl collulose in exterior two-coat house paints.

The paints were prepared using es rehioles soyabean, Iinseed, and perilla olls into which were cooked different peroentages of ethyl oellulose. The plgment formulations were the same for primers and topooats respeotively.

Verlous tests were made to show the offeots of ethyl cellulose on those properties of house paints whloh are lmportant from the standpoint of both the manufacturer and the consumer. The effects produced were obtained by:

1. The dotermination of the hiding power and gloss of the prepered samples.

2. The determination of the penotration of the exterior wood primers.

3. The determination of the brushing, sagging, and loveling properties.

4. The determinetion of the hardness and freedom from taok of the varlous paints.

5. The determination of the toughness of the paints when thoroughly dry.

6. The determination of the weatherability of the samples when exposed under ordinary conditions of temperature and humidity. 
The experimental regults obtained fran these tests were given to show the beneficlal or detrimental effects produced when ethyl cellulose wag inoorporated in the rohiole. 
HISTORICAI 
The history of art and plementetion seems to have orIgineted in Egypt. Excevetions in Cheldaee by Amerleara in 1896 revealed monuments that carried dates back to 4000 a.C. Traces c. solor were present in all the rounds, with red, blue, and yellow predomineting (16). By the time of the Roman supremacy there vere sereral so-called wite plements known. Hovever, all these vere white earthe of some sort and not plgments as we know them today. These earths were applied by mixing th glue, white of e8s, or guws.

In the elghth century coblr, en rablon alohemist, was sald to bave been well acqualntod with white lead.

The use of linseed oll es rohicle dates back as far as the tenth or olevonth contury whon inatruotions were given in the writings of Theophllus for the preparation of varalsb erom linseed oll and gum. Direotlans for rerining oll occur as early es 1350 and the use of driers has been known since the fifthteenth or s1xteenth century.

At the time of the colonization of Amerlca the use of paint as a preservative not common. The oldest mooden bulldings in imerican citles gnd towns are still unpeinted.

It was not until after the fievolution that paint as a preservative oume into general uso. It was 
usually a coarse red mixture and the manser at111 remalns in the fashion of painting barns and outhouses red.

The first white lead factory was established at Philadelphia lete in the elgbteenth century and the manufaoture of zino white was begun as early es 1850. The manufacture of mixed paints has been accredited to somo New knglanders who observed that when a Inseed oll paint was mixed with a solution of all1cate of soda an emulsion was formed, and the paint so made showed very 11ttle tendenoy to settle in the package. The flrat mixed paint was markoted in emall peckages for homo consumption and appeared about 1865 (10). The goneral use of zino oxide has had much to do with the progreas of mixed peint, for it is well known that white lead and linseed oll settle quickly in the package wh1le zinc oxide keeps the heavier lead in suepension longer.

Unt1l the reoent introduction of apecially designed primers and topcosts, house painting practice has changed very little alnce the flrst use of "ready mixed" painte. 
HHORETICAL 
An exterior house paint may be derined as a protectire couting for the preservation of aurfaces exposed to the weather. It conglete, brierly, of a pigmont, an oll or rohiole, thinner or diluent, and a drier. A paint therefore contains both volatile and non-rolatile constituents.

Practloally all commercial paints contain moro than a single oll and a single pigment, because any one ofl or plgment does not possess all the properties required for the produotion of a coating that will prove satisfactory to the ultimate oonsumer.

The most common of ell exterior painting systems has been the type in which two or throe ooats of the same paint wore applied over the surface to be painted. There were many rather obvious disadvantages to this system.

Vithin recent years there have been Introduced spocially designed primers and topoots. These peints are two quite different types of colings, both the ploments and rohiclos rarying as to typo and formuletion. This system has since became known as the "TwoCoat System" and is rapidy geining popularity. Briefly, the "Two-Coat System" is built upon the fact that the coating placed next to the wood has a vory derinite function to perform and is quito different 
from that performed by the ooeting oxposed to the atmosphere. Since the funotions performed by the upper and lower coatings are different, then it is evident that the compositions of these coatings will also diffor. The funotion of a "Two-Coat System" is for it to combline ease of brushing, loveling, rapld drying, adbosion, and elastiofty with film fallure of a typo that will give the most satiafactory surface for repainting.

All white pelnts prepared woro made acoording to the "Two-Coat System", with the exception that a single rohiele was used for both primer and topookt. This was necessary for comparison purposes.

of the non-rolatile or permanent film-forming matorials in the paint, the oll or vehicle actually Gives the resultant film the properties oharacteristio of the Iinlsh. The presenoe of pigments or resins has an effect but does not change, fundamentally, the mechanism that takes place (3).

gssentially a drying ofl is a mixture of mixed triglyoerides or fatty alds such as steario, 0le10, 11nolo10, linolenic, and so forth. hen a drying 011 is exposed to the air, it undergoes several ohanges which, acoordine to Long (4), may be divided into four seperate stages. These stages are not distinot but overlap and to some extgnt take place simultaneously. They 
are as follows:

1. Induotion Period -- This is a formative period in which oxldation plays an important role although the chemical ohanges used to characterize It are not yet in evidence.

2. Formation of Colloldal Nuclel sols(micelles)

In this stage the moleoules of the ofl are gradually arranged and foined to each other in a definito rashion thus bullding the primary structure called the nuclous or micelle. The most important change is the deorease in the number of tree double bonds lort in the oil. The change is thought to take plece somewhet as follows:<smiles>[R1]C(C)=CCC1OOC1([Z])CCC(=O)O</smiles>

3. Coagulation and Solration with consequent "set" to a solld gel -- The ability of the oll to dry or set is dependent on the presenoe of double bonds (ethylene Ilnkages). Those containing four double bonds dry faster than those with three and so forth.

4. Subsequent changes in the solld gol $111 \mathrm{~m}$-The changes in this stage are associated with the transition of liquid phese to solld and the weakenIng of the double-bonded structure es it adsorbs relatively inactive constituents such as water and 
non-oxidizing terials. Over a lone perlod or time this results in loss of elasticlty and finaliy in cracking and fallure.

Sojabean oll is not 1deal for ube in paint because of its poor drylng qualities, but it possesses the excellont characteristics of permanent elastiolty and freedom from discoloration. The relatively slowdrying of soyabean oll limits its use as the sole vehic10 for alr-drying exterior paints where the temperature conditions are rariable and never ldeal (11).

The popularity and utility of linseed ofl heve been assured by years of successful performance, and oomplete substitution by any other oil is questionable, except as the substitute oll approaches linseed in propertios (11).

The high degree of ungaturation of perilla oll causes it to dry quiokly and hard, and its rilm possesses good gloss and woather resistance, but its porformance is pecullar, especially in alr-drying Finishes.

Although the 112n produced by arying 011 is considered as a protective coating for exposed surfaces, it is far from belng perfect. Recentiy a cellulose derIretive - thyl cellulose - has been incorporated in drying olls and varniahes with the ldea or produelng properties not obtainable in the originel oil or mix- 
tures of it with other o11s. It ahortens the drying time, docroases aurface taokiness, and provides harder, more elastic, and tougher finishes (15). This has caused a consideration of 1ts use in exterior house paints. According to Sherk and Poterson (9),

.....then ethyl collulose is properly inoorporated in a drying oll or varnish, the moleoules of ethyl cellulose are considered to form a notwork whloh acts as a support for the wet film and a binder for the dry fllm. Such oomposition should proride quicker setup and faster drying of an oll or varnish flim, and should Increase the toughness of the film after drying. Thls has been found to be true If the thyl collulose is not degraded excessively by the method of incorporation. then ethyl cellulose is properly incorporated in the oll or rarnish, a oolloldal dispersion rosults, which has visoosity mon greater than that of the 011 alone under the same conditions. Thus it is possible to produce an 011 of $\mathrm{hlgh}$ riscosity without cooking it to the extent that oross linkage of the ofl molecules oocurs.

Next to the oil in injortance in an oxterior coating are the plgments. It has bean shown (3) that both the appearanoe and durability of a paint are affocted by the type, partiole size, and shape of the pigmonts used.

31nce "two-ooet" aystem was Involved, tho primer was studied first. Acoording to Robertson (6) a successful primer should meet the following requiremonts:

1. Good adhesion and obility to malntain it. 2. The retention of suffiolont degree of 
- lasticity after applioation, to respond to dimenslonel surface changes caused by nolsture and temperature varlations.

3. A degreo of hardness auficient to be compatible with the arerage topoot.

4. sibility to form aniform and non-absorbent film over all surfaces generally encountered in peinting houses.

5. A degree of hiding power sufficient to gire good appearance with a single topcoat.

6. Froedom frow cheoking, craoking, llaking, or soaling even when exposed as alngle film.

If the amount of reactive pigments suoh as lead, zine, and barium oompounds are reduced, and the percentages of inert plgments such as the titanlum compounds are increased, a combination can be selocted to give best adhesion (7).

Elasticity and Its rotention is in general

promoted by reduoing the reactivity between plement and vehicle, whioh promotes hardening and embrittlement of the film $(7)$.

Sufflolent hardness may be obtained in the film by having present in the primer a suitablo quantity of reactiro plements such as lead and zino.

The hidine power may be controlled easily by varyling the peroentage of high hiding plements such as 
the titanium compounds.

Becauce the formation of zino soaps, from the reaction between the basio zino oxide and rehiole, reoulta in 1088 of adhesion and peoling because of their high solubility in water, all zinc compounds should be omitted from the undercoat. This leaves as plgments, compounds of lead and titanium. Extenders or fillers, such as asbestine, whose purpose it is to provent sottling of tho paint and to dissipate strains in the Illm, are ususlly added to the pigments.

The lnst point in connoction with a primor designed with the abore points in mind is the plgment rolume conoentration. The usual ooneentration for a primar of this type is a plement rolume of 40\%. This ooncentration aids in producing a unform coating orer surfaces of rarying porosity, suoh as jellow plne, and has a direot bearing on the 11lm hardnoss (6).

Sat1sfactory results may be obtainod with a great variety of topcoats if a primer of this type is used. The in function of the topooat is to resist the rays of ultra-violet which cause deteriorstion of the f1lm. It so happens that of all the white pignents In common use, the titanium compounds afford the greatest protection to the rehicle, at the same time increasing the hlding power. A topeot heving a high blaing power is almost a nocessity if a "two-cont" 
system is boing used.

In general, a certain degree of chalking 1s desirable and aids in giving a clean bright surface. This property may be obtained by the inclusion of zinc compounds in the topooat. The zinc soaps that are formed gradually dissolve in the rain and are washed away -xposine fresh surfaco.

A small quantity of load compounds, such as the bas10 carbonate and sulphate, are lnoluded in order to rotain a certain amount of plastiolty in the finiah. As in the case of the primer, the proper pigment volume concentration is necessery for \& successful topoot. A plgment concentration of $27 \%$ to $30 \%$ by volum has beon found gatisfactory for topooat formalations.

\section{All exterior peints contain driers of some} typo. A drier mey be defined as a highly concentratod solution of a metallic compound whioh acts as a catalyst in the drying reaction. The solid portion of a drier is a chemical compound of motal such as load, manganese, oobalt, or zinc with a olass of substances known as naphthenic acids. The liquid portion is a petroleum diluent known to the trade as mineral spirita. The most popularly uged driers are those containing lead, manasese, and cobelt.

In paints containing lead driers there is not 
mach tendenoy for the rehicle to skin orer because it drles from the botton up. However, when lead alone is used, the films retain a persistant tackiness and oonsiderable amounts of drier must be used with resultant darkening. Aocordingly, certaln amount of mangarese or cobalt drier is used along with the lead. Manganese hardens the film to a greater extent than elther cobalt or lead, and if used by itself will cause the fllm to become brittle and orack (5).

The remining constituent of an exterlor paint is the thinner or diluent. The purpose of the thinner 18 to reduoe the viscosity of the costing to the proper brushing oonsistency. Faotors (8) to be taken Into account for the proper selection of a thinner are the rate of evaporation, solvent strength, offeot on viscosity, wotting of pigments, and effects on skinning and golling.

The use of minaxil spirits as a diluent for oxterlor house paint is rapialy replacing turpentine and other thinners because of its superior qualities. Repeated comparisons of the durability of white paints on wood, when epplied over aluminum primers and when used in the oustomary maner over white primers, have consistently shown distinot superiority in service for the palnts applied over the aluminum primers (2). The Improvesent in durabllity is usually ohown by a 
returdetion in the rate at whioh contings become ombrittled with ege and rlake from the bands of dense summer wood present in may types of softwood zumber. The benefit obtalned is greatest in the case of woods such as 3outhern Yellow Plno and Douglas Pir.

It was with this thought in mind that sevoral aluminum paints were prepared for the purpose of comparison. 
18.

RAV MATERIAIS 
The raw terlals used were ethyl cellulose, soyabean, linseod, and per1lla olls with sultable plgments, driers, and thinner.

The plgments seleoted were titanox B-30, basic cerbonate of white lead, basic sulphate of white lead, zinc oxide, aluminum powder, and asbestine. The latter compound was not a plgment but an extender or Filler. Those materials were representative of the types used in industry,

The driers seleoted for use were a $24 \%$ metal110 lead drier and a $6 \%$ metallic manganese drier. They were of the liquid type and are common to industry. The only thinner used was minoral spirits. Th1s liquid is used more or loss unirersally as a diuent for exterlor house palnts.

The properties of the raw materials are 11sted as Lollows:

T1tanox B-30 -- This pigment was manuraotured by the Titanium Plement Corp. (19). It is a true composite pigment oonsisting of $30 \%$ titanium dioxide preeipltated upon and coalesced with 70\% barium sulphate. It had apecific gravity of 4.24 and a bulking value or 35.2 pounds per gallon or 0.0283 gallons per pound. The residue on a 325 mosh soreen was $0.2 \%$. Its oll absorption was 22.0 . 
Basio Carbonate of White Load -- Th1s plgment wes manufactured by the National Lead Co. It 18 a doublo compound having the formula: $\mathrm{Pb}(\mathrm{OH})_{2} \cdot 2 \mathrm{PbCO}_{3}$. It had apoolflo gravity of 6.8 and a bulking value of 56.7 pounds per gallon or 0.0176 gallons per pound. The residue on 325 mesh screen was $0.2 \%$. Its oll absorption was 9.0 .

Basio Sulphate of Hhite Load -- This plgment was manufaotured by the Eagle-Plohor Lead Co. Th1s oompound is also known as sublimed whito load and has a composition corresponding to approximately $7 \% 7.00$, 16\% $\mathrm{PbO}$, and $77 \% \mathrm{PbSO}_{4}$. It had a apeolrlo grarity or 0.41 and bulking velue of 53.4 pounds per gellon or 0.0187 gallons per pound. The residue on 325 mesh soreen was $0.5 \%$. Its o1l absorption wa 12.1 . zino 0xide -- This pigment was manufactured by the New Jersey zinc Co. (17). It is the standard "Lead Free" zino oxide used for general paint maraoture. It had a specifle gravity of 5.66 and a bulking ralue of 47.1 pounds per gallon or 0.0212 gellons per pound. The residue on a 325 mesh sereen was $0.5 \%$. Its o1l absorption was 18.6.

Aluminum Powder -- This powder was manufactured by the Aluminum Co. or Amerios (13). It was apecifiod as their standard rarnish powder No. 321. It had apeoiflo gravity of 2.55 and a bulking value of 
21.3 pounds per gallon or 0.0470 gallons per pound. Its mesh or soreen rating was 140 . Asbestine -- Thlo extender was manufactured by the International PUlp Co. It had a composition approximately as follows: $92.0 \%$ magnesium silicate, $4.0 \%$ IImo (as allicate) and $4.0 \%$ water of orystallization, It had spectelo gravity of 2.85 and a bulking value or 23.7 pounds por gallon or 0.0421 gallons per pound. The residue on 325 mesh screen $1.0 \%$. Its oil absorption was 20.4 .

Ethyl Cellulose - This oellulose derivative was obtalned from the Dow Chemleal Co. (14) under the trade name of "Ethooel". It had a standard ethoxy content of $47.5 \%$ to $49.0 \%$ and a speciflo gravity of 1.14 . It was furnlahed as a white granular solld in a 20 contipoise Visoosity grade.

Soyabean 011 -- This oil was alkall refined by the Blsbee Co. It was pale yellow in oolor, had a specific gravity of 0.925 , an index of refraction of 1.473, an lodine number of 123 to 132 and saponification value of 190 to 195 . Its eald value was 1 to 3.

Iinsood 011 - Ihis oll was alkall rofinod by Spencer Kellogg \& Sons Inc. It was pale yellow in color, had a spoofflo gravity of 0.931 to 0.935 , an index of refraotion of 2.478 , an lodine number of 175 to 190 and a seponifioation value of 188 to 196. Its acil value 
was 1 to 4 .

Perilla 011 - Th1s oll was alkall reflned by the Blsbee Co. It was pale yellow in color, had a specific gravity of 0.933 , an index of refraction of 1.482, an iodine number of 200 to 206 and a aponiflcation value of 190 to 192 . Its acid ralue was 0.5 (hax.).

Mineral Spirits -- This thinner was a product of the Standard $011 \mathrm{Co}$. of $\mathrm{Ky}$. It was a petroleum distillate derived from those fractions of petroleum between motor gasoline and kerosene. It was weter-white in color and had a specific gravity of 0.780 . The dist1llation range was from $312^{\circ} \mathrm{F}$ to $412^{\circ} \mathrm{F}$ and 1 ts flash point was $102^{\circ} \mathrm{F}$. Its weight per gallon was 6.50 pounds. Lead Drier -- This compound was manufactured by the Nuodex Products Inc. (18). It hes a clear yellow solution and had speciflc gravity of 1.150. Tho solid portion of the drier wes a chemical compound of lead with cyclopentane carboxylic acid. The 11quid portion was mineral spirits. The metal content was $24 \%$ lead. Manganese Dr1er -- Th18 eompound was also manufectured by the Nuodex Products Inc. (18). It was a olear brown viscous solution and had a spocific gravity of 0.980 . This drier we composed similarly to the lead dr1er, but the metal content was $6 \%$ manganese. 
23.

GEMERAL PROCEDURS 
The incorporation of the various percentages of ethyl oellulose in the retined o1le (soyabean, IInsoed, and porilla) was first undertaken. The mothod of Inoorporation consiated brieriy in heating a sultable quantity of the 011 to $450^{\circ} \mathrm{F}$ in stalnless steol cookor (11g. 1), at whioh temperature the required amount of othyl oellulose was added. The heatling was thon continued unt1l the cook reached temperature of $570^{\circ}$. Th1s temerature was maintalned unt1l any gel formation was broken down, as was eridenced by the inspection of samplea taken at frequent interrels. The cook was allowed to 0001 to room temperature and a sufficlent quantity of the ofl stored for use as vohicle. A samplo of the refined oll was also hoat bodied for 2 hours at $625^{\circ} \mathrm{T}$.

All the cooks were propared under an tmosphere of carbon dloxide in order to prevent darkening of the o1l by oxidation. A summary of the cooks prepared is given in Table I.

Several olls were also prepared by mixing varlous percentages or either refined or heat bodied soyabean oll with the $15 \%$ ethyl cellulose - soyabean 011 cook to give o1ls containing $2,4,6$, and 8 percent ethyl cellulose respectively. Another 6\% ethyl oellu1080 - sojabean 011 cook was prepared and suffioient 


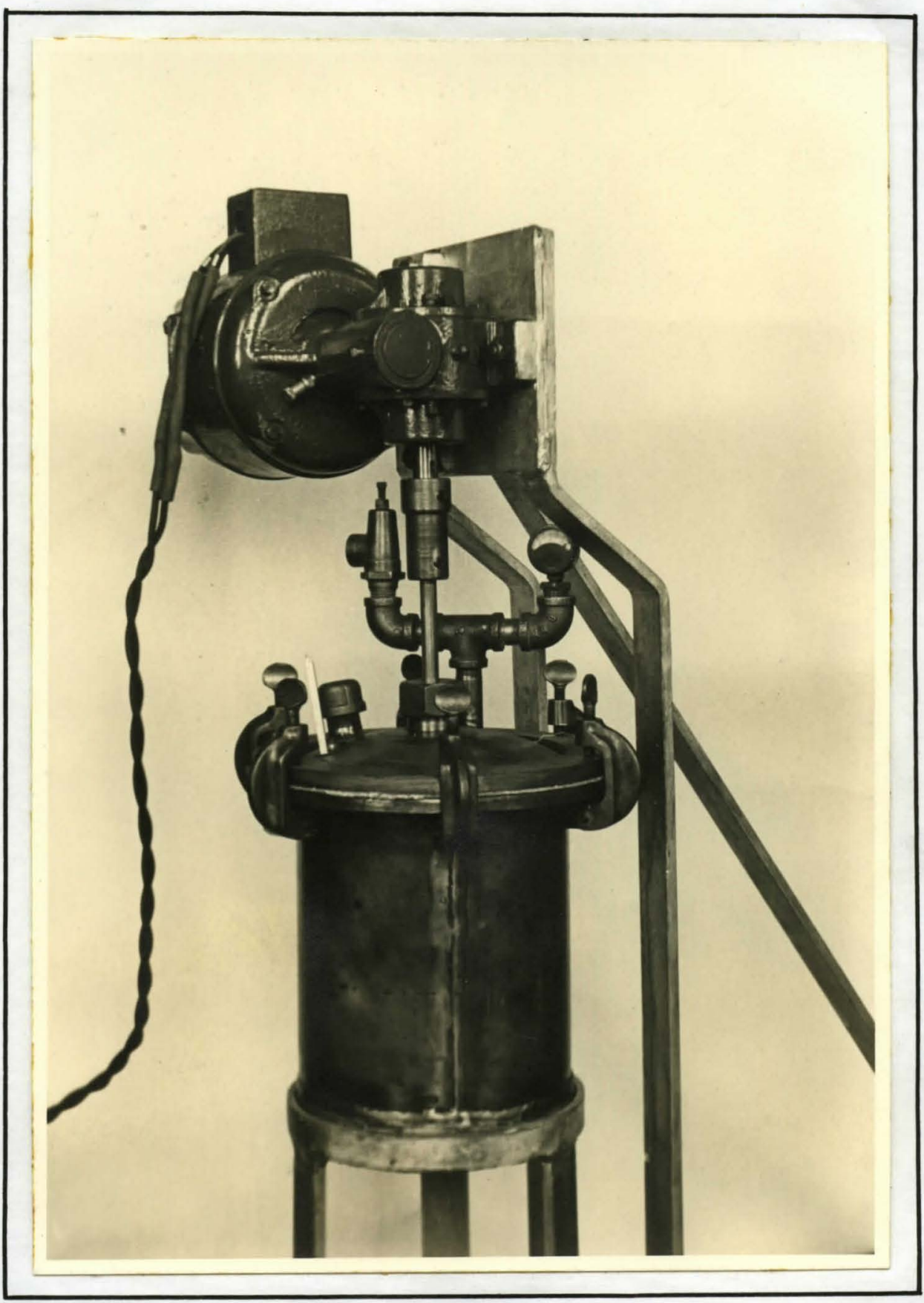

Figure 1

Stainless Steel Cooker 


\author{
TABLE I \\ SUMDARY OF OII COOKS PREPARED
}

011 Peroent Ethocel Cook Held 5p. Gr. or Ethooel Added Toup. $0 \mathrm{~F}$ Min. Temp. ${ }^{\circ} \mathrm{F}$

Cook

\#/Gel.

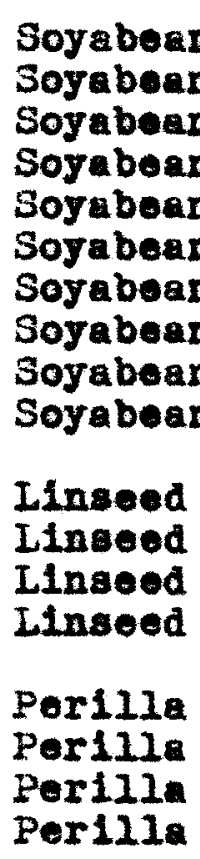

0

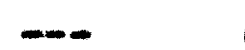

$625 \quad 120$

7.92

7.68

7.73

450

450

450

450

450

450

450

400

$570 \quad 35$

$570 \quad 20$

$570 \quad 25$

$570 \quad 30$

$570 \quad 30$

7.77

7.79

20

15

20

$570 \quad 35$

$570 \quad 35$

7.81

$570 \quad 50$

7.83

7.92

57050

8.02

0

450

450

450

$570 \quad 35$

$570 \quad 20$

7.80

$570 \quad 25$

$570 \quad 30$

7.82

7.86

7.87

0

$---$

$570 \quad 35$

7.86

2

570

25

7.86

450

57030

7.88

6

450

57035

7.94 
quantitios remored at intervals to obtain aamples or the solld gel stage, the liquid gel stage, the liquid stage, and the final cook.

Sultable plements and formulations were then seleoted to be used in the preparation of the exterior peints. In Table II are given the plgment formulations selocted as belng typicel of those used in modern "twocoat" painting systems.

The apeo1f10 gravities of all $011 \mathrm{~s}$ and driers and the diluent were then determined by moans of a peint plenomoter of the type developed by the Krebs Plgment Co.

The preparation of the samples was then undertaken. The required amounts of oll and plement were weighed out and thoroughly ixed to form atiff paste. Th1s paste was then passed through a rolier-typo paint mi11 (FIg. 2). The millea pasto was reground unt11 complete wetting of the pigment was obtained, efter whioh it was placed in plut oans and the proper amounts of thinner and drier edded. In the preparation of the aluminum paints the plgment was welghed out and stirred into a small portion of the rehiole, the remainder beling added when the powder was thoroughly wetted. The proper amount of thinner to add was dotermined by mothod doroloped by the Krebs Plement Co. 
TABLE II

SUMRARY OF PIGMENT FORUULATIONS

Primer Pormulation (inite) Plgment Volume $40 \%$

T1tanox B-30....................57.5\% By vt. Bas10 Carbonate of Finite Lead.......37.5\% By wt. Asbestine.....................25.0\% By Vit.

Topcont Formulation (Vhite) Pigment Volume 28\%

Titanox B-30................40.0\% By Wt. Bas10 Carbonate of Thite Lead......229.0\% By wt. Bas10 Sulphate of unlte Lead........11.0\% By wt. ..Ino oxide.....................20.0\% By 1.t.

Primer Pormulation (Aluminum) Pigment Volume $6.6 \%$ Standard Aluminum Varnish Powder...200.0\% By rt. 
and used at present by several of the larger paint ooncerns. It consisted briefly of measuring the viscosity or consistenoy of a given sample by mans of a Stormer V1s0osimeter (FIg. 3) equipped with a spoolal paddle agitator in place of the regulation cylinder and cup. The apparatus was proviously stendardized by lmersing the ogitator to dopth suffiolent to roquire dofinito time for 100 revolutions of the paddle in a peint of known or standard riscosity.

kineral spirits was added to the prepared samples in an mount aufficient to reduce the viscosity to 1 inited range $(26.0$ to 34.0 seconds with 250 grams for the primers and 30.0 to 40.0 seconds with 200 grams for the topcoats).

The proper amounts of lead and manganese driers were then added to the thinned samples by means of burette. The percent of driers added $10.5 \%$ metall10 lesd and $0.05 \%$ tallic manganese) was the same for each sample and was based upon the wolght of the oll minus the ethyl collulose, in order that any drying sffect caused by the ethyl oellulose could be readily noticed.

In Table III is givon a summary of the ofls as used in this investigation. Tables IV and V present a summary of the primers and topooats prepered for 


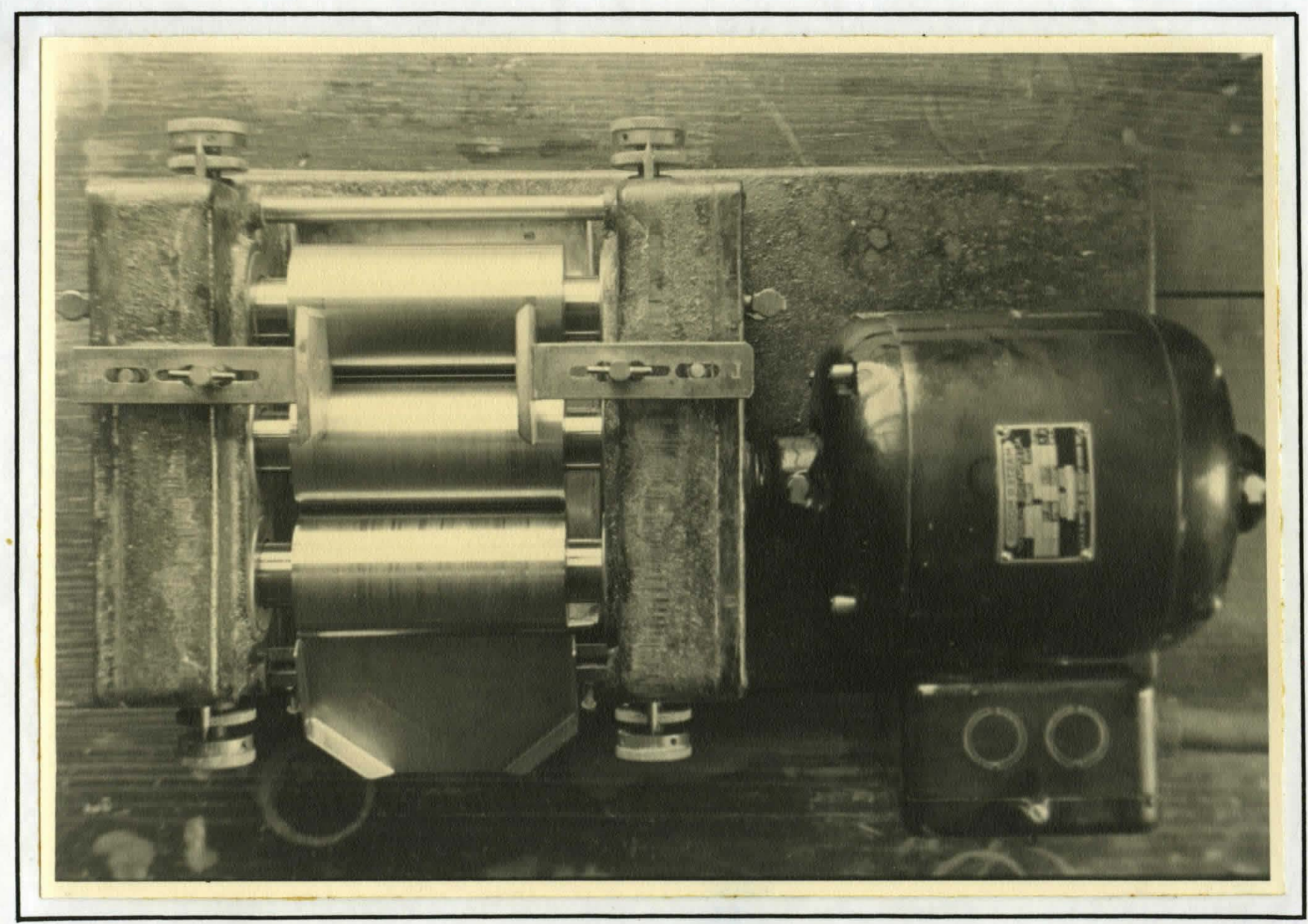

Figure 2

Roller-Type Paint Mill 


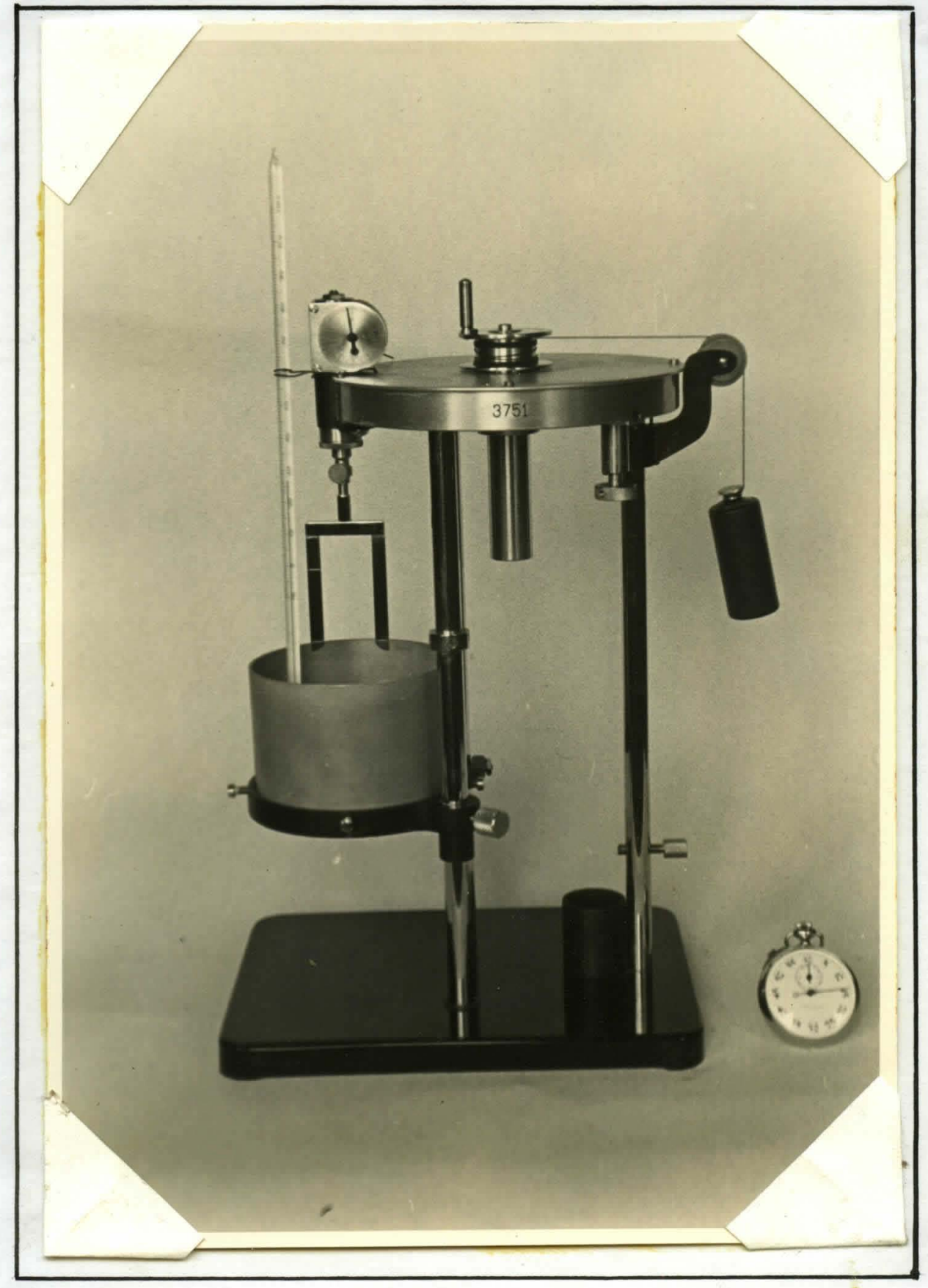

Figure 3

Stormer Viscosimeter 
teating. Bealdes the test amples, three commercial

"two-coat systems" were used for comparison purposes. 
SUMWIYY OF OILS USED IN EXTERIOR PAINTS

Serles 1 -- Alkall refined soyabean ofl cooked with $0,2,4,6,8,10,15$, and 20,6 thyl cellulose.

Serios 2 - $15 \%$ ethyl celluloso bodied soyabean oll added to heat bodied sorabean oll to give samples containing $2,4,6$, and $8 \%$ thyl cellulose.

Sories 3 -- $15 \%$ ethyl cellulose bodled soyabean oll added to alkali refined soyabean oll to give samples containing $2,4,6$, and $8 \%$ othyl cellulose.

Series 4 -- Alkali refined linseed oll oooked with $0,2,4$, and $6 \%$ thyl cellulose.

Serles 5 -- Alkall refined perilla oll cooked with $0,2,4$, and $6 \%$ ethyl cellulose.

Serles 6 -- Alkall refined soyzbean oll cooked with $6 \%$ othyl oellulose. At intervals the following samples were removed: One from the oloudy gel stage. one from the solid gol stage. Ono from the liquid gel stage. Two from the liquid stage. 
TABLE IV

SUMAARY OP PRIMER FORUULATIONS PREPARED TOR TESTING

No.

011

Serles Percent 011/Thinner Type No. Ethooel Rat1o

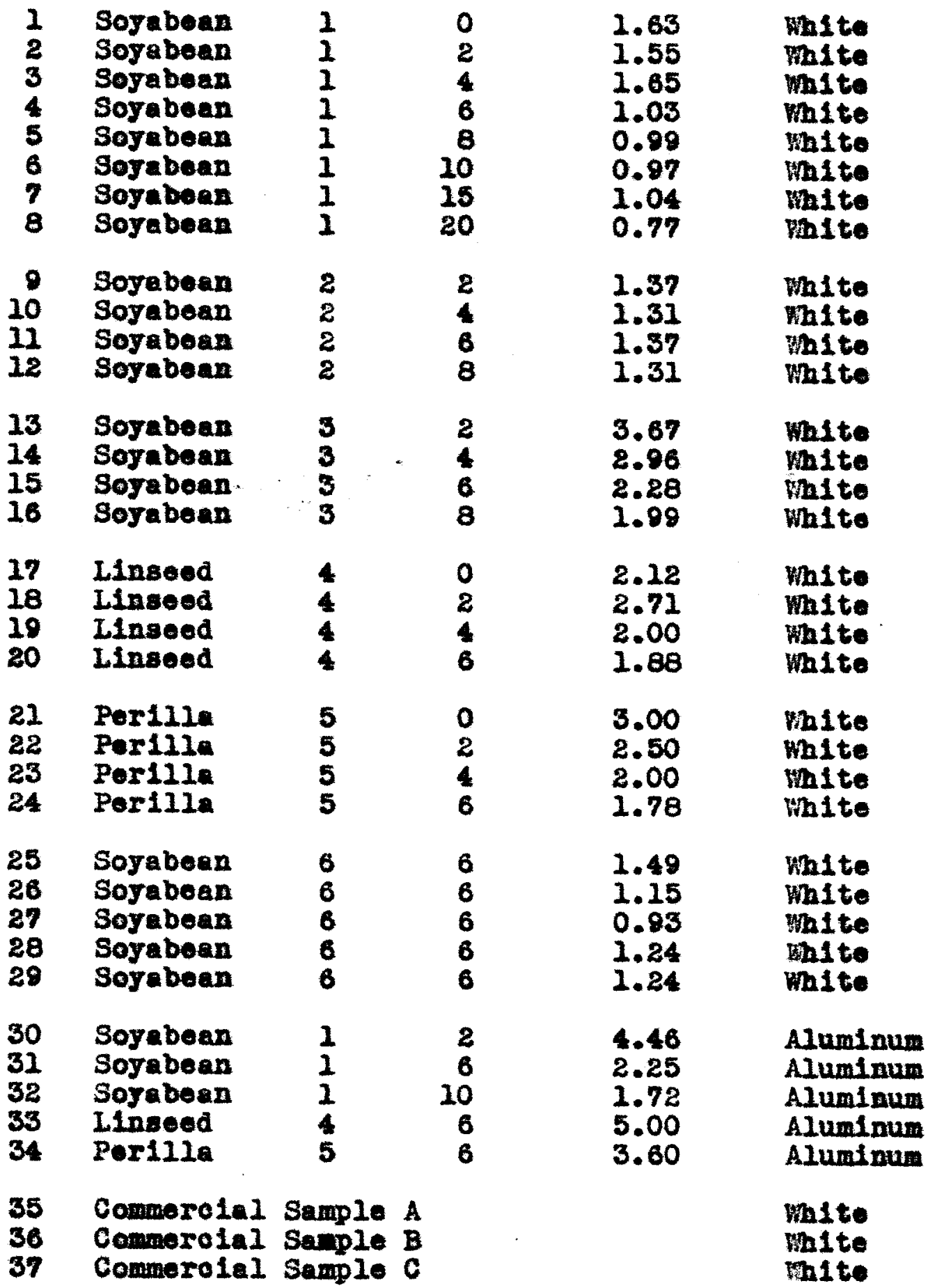


TABLE V

SUMAARY OF TOPCOAT RORMULATIONS PREPARED FOR TESTING

\begin{tabular}{|c|c|c|c|c|c|}
\hline No. & 011 & $\begin{array}{c}\text { Series } \\
\text { Ho. }\end{array}$ & $\begin{array}{l}\text { Peroent } \\
\text { Ethocel }\end{array}$ & $\begin{array}{c}011 / \text { Thinner } \\
\text { Rat10 }\end{array}$ & Type \\
\hline $\begin{array}{l}38 \\
39 \\
40 \\
41 \\
42 \\
43 \\
44 \\
45\end{array}$ & $\begin{array}{l}\text { Soyabean } \\
\text { Soyabean } \\
\text { Soyabean } \\
\text { Soyabean } \\
\text { Soyabean } \\
\text { Soyabean } \\
\text { Soyaboan } \\
\text { Soyaboan }\end{array}$ & $\begin{array}{l}\frac{1}{1} \\
1 \\
1 \\
1 \\
1 \\
1 \\
1\end{array}$ & $\begin{array}{r}0 \\
2 \\
4 \\
6 \\
8 \\
10 \\
15 \\
20\end{array}$ & $\begin{array}{l}4.40 \\
2.53 \\
2.09 \\
1.70 \\
1.33 \\
1.24 \\
1.46 \\
0.94\end{array}$ & 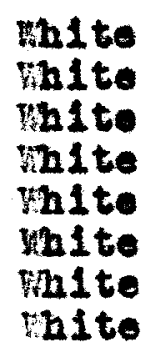 \\
\hline $\begin{array}{l}46 \\
47 \\
48 \\
49\end{array}$ & $\begin{array}{l}\text { Soyaboun } \\
\text { Soyaboan } \\
\text { Soyaboan } \\
\text { Soyaboan }\end{array}$ & $\begin{array}{l}2 \\
2 \\
2 \\
2\end{array}$ & $\begin{array}{l}2 \\
4 \\
6 \\
8\end{array}$ & $\begin{array}{l}0.95 \\
0.88 \\
1.28 \\
1.13\end{array}$ & 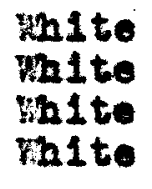 \\
\hline $\begin{array}{l}50 \\
51 \\
52 \\
53\end{array}$ & $\begin{array}{l}\text { Soyaboan } \\
\text { Soyabean } \\
\text { Sojabean } \\
\text { Soyabean }\end{array}$ & $\begin{array}{l}3 \\
3 \\
3 \\
3\end{array}$ & $\begin{array}{l}2 \\
4 \\
6 \\
8\end{array}$ & $\begin{array}{l}5.87 \\
3.93 \\
3.95 \\
3.25\end{array}$ & $\begin{array}{l}\text { Nhito } \\
\text { inite } \\
\text { wite } \\
\text { mite }\end{array}$ \\
\hline $\begin{array}{l}54 \\
55 \\
56 \\
57\end{array}$ & $\begin{array}{l}\text { LInseed } \\
\text { LInseed } \\
\text { Linseed } \\
\text { IInseed }\end{array}$ & $\begin{array}{l}4 \\
4 \\
4 \\
4\end{array}$ & $\begin{array}{l}0 \\
2 \\
4 \\
6\end{array}$ & $\begin{array}{l}3.88 \\
3.98 \\
3.27 \\
3.27\end{array}$ & 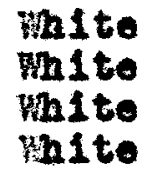 \\
\hline $\begin{array}{l}58 \\
59 \\
60 \\
61\end{array}$ & $\begin{array}{l}\text { Perilla } \\
\text { Por } 111 \mathrm{a} \\
\text { Porilia } \\
\text { Porilla }\end{array}$ & $\begin{array}{l}5 \\
5 \\
5 \\
5\end{array}$ & $\begin{array}{l}0 \\
2 \\
4 \\
6\end{array}$ & $\begin{array}{l}6.00 \\
3.60 \\
3.02 \\
2.60\end{array}$ & $\begin{array}{l}\text { mite } \\
\text { inite } \\
\text { mito } \\
\text { thito }\end{array}$ \\
\hline $\begin{array}{l}62 \\
63 \\
64 \\
65 \\
66\end{array}$ & $\begin{array}{l}\text { Soyaboan } \\
\text { Soyaboan } \\
\text { Soyabean } \\
\text { Soyabean } \\
\text { Soyaboan }\end{array}$ & $\begin{array}{l}6 \\
6 \\
6 \\
6 \\
6\end{array}$ & $\begin{array}{l}6 \\
6 \\
6 \\
6 \\
6\end{array}$ & $\begin{array}{l}2.39 \\
1.38 \\
1.63 \\
1.63 \\
1.56\end{array}$ & $\begin{array}{l}\text { mite } \\
\text { mite } \\
\text { mite } \\
\text { mite } \\
\text { mite }\end{array}$ \\
\hline $\begin{array}{l}67 \\
68 \\
69\end{array}$ & $\begin{array}{l}\text { Commercia: } \\
\text { Commercia } \\
\text { Commerola }\end{array}$ & $\begin{array}{l}1 \text { Sample } \\
1 \text { Sample } \\
1 \text { Sample }\end{array}$ & $\begin{array}{l}\mathrm{A} \\
\mathrm{B} \\
\mathrm{C}\end{array}$ & & $\begin{array}{l}\text { Winite } \\
\text { inite } \\
\text { white }\end{array}$ \\
\hline
\end{tabular}


36.

PART I

HIDING POYTR 
THEORETICAL

H1ding power may be derlned es that property of paint or coating whioh enables it to obliterate completely any aurface over whioh it is spread.

Whon light falls upon an objoct, part of 1t is refleoted at the surface, part of it $1 \mathrm{~s}$ absorbed, and the reminder transmitted. wen light falls upon painted surfaoe part is reflected, both by the film surface and the individual pigment partioles within the 111m. The remalnder is oither absorbed by the film or 18 transmltted to the baokground. Any light reaching the beckground is again aither reflected or absorbed depending upon the 11ghtness or darkness of the surface. An alternato light and dark background will rerleot as contrasts through the paint rilm to show up as incamplete hiding (3).

The hiding power of a paint ooting therefore depends upon the quantity of light that is rerlected or absorbed before it reaches the beokground. The amount of Ilght refleotod depends in turn upon the particlo 81 ze of the pigment and the difference in the refreetive indices of the rehicle and pigment (3).

An instrument used to determino the absolute blding power of paints is the Prund Cryptomoter, dereloped by A.H. Prund and introduced in 1930. 
The oryptometer consiste primarily of two plates of glaes whose optically ilat surfaces are separated by a fixed angle in whioh a wedge-shaped film of paint is formed. The bottom plate of gless is opaque and is fitted with convenient arrangement for determining and mosuring the thioknoss of the rilm or palnt neoessary to hlde an underlying surface completely. The top plate is transparent and fitted with motal pegs for mainteining oonstant angle botween the plates. The biding power in square foet per gallon is giten by the equation:

$$
\begin{aligned}
\text { H.P. } & =4.07 / \mathrm{K} \text { IL where, } \\
\text { H.P. } & =\text { Hlding power in square roet/gallon. } \\
X & =\text { Top plate constant in om. }=0.0007 \\
L & =\text { Soale reading on lower plate in m. }
\end{aligned}
$$


EXPERIMENTAL WORK

A wodge-ahaped samplo of tho paint was firat formed by placing 1 to 2 oc of the sample on the bottom plate, orer which wes placed the transparent plate containlag the motel pegs. By sllding the top plate backward and forward, aherp line of demareation lohowing the line of complete hiding) alternately appeared and disppured. At this point the thlokness of the film was just sufficient to obliterate the bakground, and a reading taken on the engrared scale on the bottos plato. This prooedure was repeated sereral times in order to obtaln an average value, which was then converted into square fsst por gellon by moans of the equation given previously.

The results of the tests were roported in Tables VI and VII as the hiding power in square foet of surface covered per galion of paint. 
HIDING POHER OP EXTERIOR HOUSE PRIMERS

\begin{tabular}{|c|c|c|c|c|c|}
\hline No. & 012 & $\begin{array}{l}\text { Ser1e* } \\
\text { No. }\end{array}$ & $\begin{array}{l}\text { Peroent } \\
\text { Rthooel }\end{array}$ & $\begin{array}{c}\text { Cryptometer } \\
\text { Reading } \\
\text { M.M. }\end{array}$ & $\begin{array}{l}\text { Hiding Powor } \\
\text { Sq. It./Gal. }\end{array}$ \\
\hline $\begin{array}{l}1 \\
2 \\
3 \\
4 \\
5 \\
6 \\
7 \\
8\end{array}$ & $\begin{array}{l}\text { Soyabean } \\
\text { Soyabean } \\
\text { Soyabean } \\
\text { Soyabean } \\
\text { Soyabean } \\
\text { Soyabean } \\
\text { Soyaboan. } \\
\text { Soyabean }\end{array}$ & $\begin{array}{l}1 \\
1 \\
1 \\
1 \\
1 \\
1 \\
1 \\
1\end{array}$ & $\begin{array}{r}0 \\
2 \\
4 \\
6 \\
8 \\
10 \\
15 \\
20\end{array}$ & $\begin{array}{l}12 \\
13 \\
13 \\
14 \\
14 \\
15 \\
14 \\
15\end{array}$ & $\begin{array}{l}484 \\
447 \\
447 \\
415 \\
415 \\
387 \\
415 \\
387\end{array}$ \\
\hline $\begin{array}{r}9 \\
10 \\
11 \\
12\end{array}$ & $\begin{array}{l}\text { Soyabean } \\
\text { Soyaboan } \\
\text { Soyabean } \\
\text { Soyabean }\end{array}$ & $\begin{array}{l}2 \\
2 \\
2 \\
2\end{array}$ & $\begin{array}{l}2 \\
4 \\
6 \\
8\end{array}$ & $\begin{array}{l}14 \\
13 \\
14 \\
13\end{array}$ & $\begin{array}{l}415 \\
447 \\
415 \\
447\end{array}$ \\
\hline $\begin{array}{l}13 \\
14 \\
15 \\
16\end{array}$ & $\begin{array}{l}\text { Soyabean } \\
\text { Soyabean } \\
\text { Soyabran } \\
\text { Soyabean }\end{array}$ & $\begin{array}{l}3 \\
3 \\
3 \\
3\end{array}$ & $\begin{array}{l}2 \\
4 \\
6 \\
8\end{array}$ & $\begin{array}{l}13 \\
13 \\
13 \\
14\end{array}$ & $\begin{array}{l}447 \\
447 \\
447 \\
415\end{array}$ \\
\hline $\begin{array}{l}17 \\
18 \\
19 \\
20\end{array}$ & $\begin{array}{l}\text { Inseed } \\
\text { Linseed } \\
\text { Linseed } \\
\text { Linseed }\end{array}$ & $\begin{array}{l}4 \\
4 \\
4 \\
4\end{array}$ & $\begin{array}{l}0 \\
2 \\
4 \\
6\end{array}$ & $\begin{array}{l}14 \\
24 \\
15 \\
15\end{array}$ & $\begin{array}{l}415 \\
415 \\
387 \\
387\end{array}$ \\
\hline $\begin{array}{l}21 \\
22 \\
23 \\
24\end{array}$ & $\begin{array}{l}\text { Portila } \\
\text { Peril1a } \\
\text { Perilia } \\
\text { Perilla }\end{array}$ & $\begin{array}{l}5 \\
5 \\
5 \\
5\end{array}$ & $\begin{array}{l}0 \\
2 \\
4 \\
6\end{array}$ & $\begin{array}{l}13 \\
13 \\
14 \\
14\end{array}$ & $\begin{array}{l}447 \\
447 \\
415 \\
415\end{array}$ \\
\hline $\begin{array}{l}25 \\
26 \\
27 \\
28 \\
29\end{array}$ & $\begin{array}{l}\text { Soyabean } \\
\text { Soyabean } \\
\text { Soyabean } \\
\text { Soyabean } \\
\text { Soyabean }\end{array}$ & $\begin{array}{l}6 \\
6 \\
6 \\
6 \\
6\end{array}$ & $\begin{array}{l}6 \\
6 \\
6 \\
6 \\
6\end{array}$ & $\begin{array}{l}24 \\
14 \\
14 \\
14 \\
13\end{array}$ & $\begin{array}{l}415 \\
415 \\
415 \\
415 \\
447\end{array}$ \\
\hline $\begin{array}{l}35 \\
36 \\
37\end{array}$ & $\begin{array}{l}\text { Commercia] } \\
\text { Domero Ia] } \\
\text { Commercia] }\end{array}$ & $\begin{array}{l}\text { Sample } \\
\text { Sample } \\
\text { Sample }\end{array}$ & $\begin{array}{l}A \\
B \\
C\end{array}$ & $\begin{array}{l}13 \\
13 \\
12\end{array}$ & $\begin{array}{l}447 \\
447 \\
484\end{array}$ \\
\hline
\end{tabular}



Ho. 011 Series Peroont Cryptemeter Hiding Power No. Ethooel Roading Sq. Pt./Gal. M.M.

$\begin{array}{ll}38 & \text { Soyabean } \\ 39 & \text { Soyabean } \\ 40 & \text { Sojabean } \\ 41 & \text { Soyabean } \\ 42 & \text { Sojabean } \\ 43 & \text { Sojabean } \\ 44 & \text { Soyabean } \\ 45 & \text { Sojabean } \\ 46 & \text { Soyabean } \\ 46 & \text { Soyabean } \\ 47 & \text { Soyabean } \\ 48 & \text { Soyabean } \\ 49 & \\ 50 & \text { Soyabean } \\ 51 & \text { Soyabean } \\ 52 & \text { Soyaboan } \\ 53 & \text { Soyabean }\end{array}$

$\begin{array}{rr}1 & 0 \\ 1 & 2 \\ 1 & 4 \\ 1 & 6 \\ 1 & 8 \\ 1 & 10 \\ 1 & 15 \\ 1 & 20\end{array}$

12

23

23

13

13

24

14

14

14

13

14

13

13

12

13

13

15

13

13

13

14

12

12

23

14

14

13

13

23

13

12

12
484

447

447

447

447

425

415

415

415

447

415

447

447

484

447

447

387

447

447

447

415

484

484

447

415

415

447

447

447

447

484

484

* Rofer to Table III 


\section{conciosions}

When the results obtained in each series ware compared aocording to the ethyl cellulose content. It wes readily seen that, In general. the hialng power decreased with inoreasing celluloes content.

This may be explalned upon the basis that when the olls were oooked with rarying amounts of ethyl $0011 u 1080$. those containing higher peroentagos vere also higher in Viseosity. Sinoe all gamples were "out" to approximately the same riscosity with minoral opirita the higher bodied olls required lerger amounts or d11uent. Thus the hiding power would naturally decrease as more non-hiding waterlal was added to the sample. A point in faror of those paints oontaining high ethyl oellulose contents is the inorease in total volume per unit rolume of o11.

The primers were about equal in hiding power to the topeoats ahowing that the latter had e. superior plement formulation sinoe the plezment rolume ratio was lower. It may also be seen that the test paints were equal in blalng power to the commerolal mamples. 
43.

PART II

cLoss 


\section{MEORETICAI}

Qlose may be cefined as the ablilty of a surraoe to refloot 11 ght regulariy (3). A comon wothod of measurement is the observation of how good a mirror the partioular surface may be.

The type of glose enoountered in painted surfaces is that which has to do with the degree of perfootion of the surface of the material. In geteral, the elossy appearanoe of coated aurfaces is the result of the qualities of surface refleotion wioh are charaoter1stie of the surface as a whole.

As in several other teste of this nuture, the results depend to a large degree upon the buman factor involved. Types and conditions of eurfeoes ugualiy have an orreot. 
The qualitative estimation of the glose of the samples propared wes determined by oosting surfaces of both brlok and cardboard. The samples ware thoroughly dried and compared with one another for the "nirror" effeot produced by their ooted surfaces. The paint. were appl1ed by zeans of a brush, two coats belng neoesary before aulteble variations or differenees were obtelned.

The results of the tests were reported in Tables VIII and IX on the basis of ratinge from a through - i representing those surfaces which were rexy glossy, and I representing those whloh were very liat or dull. 


\begin{tabular}{|c|c|c|c|c|c|}
\hline Ho. & 011 & $\begin{array}{c}\text { Seriez } \\
\text { Ho. }\end{array}$ & $\begin{array}{l}\text { Percent } \\
\text { Bthocel }\end{array}$ & $\begin{array}{l}\text { Ratin } \\
\text { Cardboard }\end{array}$ & $8_{\text {Brik }}$ \\
\hline $\begin{array}{l}2 \\
2 \\
3 \\
4 \\
5 \\
6 \\
7 \\
8\end{array}$ & $\begin{array}{l}\text { Soyabean } \\
\text { Soyabean } \\
\text { Soyabean } \\
\text { Soyabean } \\
\text { Soyabaan } \\
\text { Soyabean } \\
\text { Soyabean } \\
\text { Soyabean }\end{array}$ & $\begin{array}{l}1 \\
1 \\
1 \\
1 \\
1 \\
1 \\
1 \\
1\end{array}$ & $\begin{array}{r}0 \\
2 \\
4 \\
6 \\
8 \\
10 \\
15 \\
20\end{array}$ & $\begin{array}{l}\mathbf{Z} \\
\mathrm{E} \\
\mathrm{D} \\
\mathbf{F} \\
\mathbf{E} \\
\mathrm{E} \\
\mathrm{E} \\
\mathbf{E}\end{array}$ & $\begin{array}{l}\mathbf{F} \\
\mathrm{B} \\
\mathrm{B} \\
\mathrm{E} \\
\mathbf{F} \\
\mathrm{D} \\
\mathrm{C} \\
\mathbf{P}\end{array}$ \\
\hline $\begin{array}{r}9 \\
10 \\
11 \\
12\end{array}$ & $\begin{array}{l}\text { Soyabean } \\
\text { Soyaboan } \\
\text { Soyaboan } \\
\text { Soyabann }\end{array}$ & $\begin{array}{l}2 \\
2 \\
2 \\
\mathbf{2}\end{array}$ & $\begin{array}{l}2 \\
4 \\
6 \\
8\end{array}$ & $\begin{array}{l}\mathbf{E} \\
\mathbf{E} \\
\mathbf{Z} \\
\mathbf{D}\end{array}$ & $\begin{array}{l}\mathbf{E} \\
\mathbf{F} \\
\mathbf{F}\end{array}$ \\
\hline $\begin{array}{l}13 \\
14 \\
15 \\
16\end{array}$ & $\begin{array}{l}\text { Soyabean } \\
\text { Soyabean } \\
\text { Soyabean } \\
\text { Soyabean }\end{array}$ & $\begin{array}{l}3 \\
3 \\
3 \\
3\end{array}$ & $\begin{array}{l}2 \\
4 \\
6 \\
8\end{array}$ & $\begin{array}{l}\mathbf{E} \\
\mathbf{E} \\
\mathbf{B} \\
\mathbf{E}\end{array}$ & $\begin{array}{l}\mathbf{E} \\
\mathbf{F} \\
\mathbf{B} \\
\mathbf{B}\end{array}$ \\
\hline $\begin{array}{l}17 \\
18 \\
19 \\
20\end{array}$ & $\begin{array}{l}\text { Linseed } \\
\text { IInseed } \\
\text { Linceed } \\
\text { Lingeed }\end{array}$ & $\begin{array}{l}4 \\
4 \\
4 \\
4\end{array}$ & $\begin{array}{l}0 \\
2 \\
4 \\
6\end{array}$ & $\begin{array}{l}B \\
C \\
C \\
C\end{array}$ & $\begin{array}{l}\mathbf{B} \\
\mathbf{B} \\
\mathbf{B} \\
\mathbf{B}\end{array}$ \\
\hline $\begin{array}{l}21 \\
22 \\
23 \\
24\end{array}$ & $\begin{array}{l}\text { Porilia } \\
\text { Porilia } \\
\text { Porilia } \\
\text { Perilia }\end{array}$ & $\begin{array}{l}5 \\
5 \\
5 \\
5\end{array}$ & $\begin{array}{l}0 \\
2 \\
4 \\
6\end{array}$ & $\begin{array}{l}\mathbf{B} \\
\mathbf{B} \\
\mathbf{B} \\
\mathbf{B}\end{array}$ & $\begin{array}{l}\mathbf{A} \\
\mathbf{A} \\
\mathbf{A} \\
\mathbf{A}\end{array}$ \\
\hline $\begin{array}{l}25 \\
26 \\
27 \\
28 \\
29\end{array}$ & $\begin{array}{l}\text { Soyaboan } \\
\text { Soyabean } \\
\text { Soyabean } \\
\text { Soyaboan } \\
\text { Soyabean }\end{array}$ & $\begin{array}{l}6 \\
6 \\
6 \\
6 \\
6\end{array}$ & $\begin{array}{l}6 \\
6 \\
6 \\
6 \\
6\end{array}$ & $\begin{array}{l}\mathbf{F} \\
\mathbb{E} \\
\mathbf{E} \\
\mathbf{E} \\
\mathbf{C}\end{array}$ & $\begin{array}{l}F \\
D \\
F \\
D \\
D\end{array}$ \\
\hline $\begin{array}{l}35 \\
36 \\
37\end{array}$ & $\begin{array}{l}\text { Commercla. } \\
\text { Commercia. } \\
\text { Commerola. }\end{array}$ & $\begin{array}{l}1 \text { Samplo } \\
1 \text { Semplo } \\
1 \text { Sample }\end{array}$ & $\begin{array}{l}\mathbf{A} \\
\mathbf{B} \\
\mathbf{C}\end{array}$ & $\begin{array}{l}\mathbf{B} \\
\mathbf{B} \\
\mathbf{B}\end{array}$ & $\begin{array}{l}\mathbf{B} \\
\mathbf{B} \\
\mathbf{C}\end{array}$ \\
\hline
\end{tabular}


TABIS IX

GLOSS OF EXTERIOR HOUSE TOPCOATS

\begin{tabular}{|c|c|c|c|c|c|}
\hline No. & 011 & $\begin{array}{c}\text { Series } \\
\text { No. }\end{array}$ & $\begin{array}{l}\text { Porcent } \\
\text { Tthocel }\end{array}$ & Cardbo & Brick \\
\hline $\begin{array}{l}38 \\
39 \\
40 \\
41 \\
42 \\
43 \\
44 \\
45\end{array}$ & $\begin{array}{l}\text { Soyabean } \\
\text { Soyaboan } \\
\text { Soyabean } \\
\text { Soyabean } \\
\text { Soyabean } \\
\text { Soyabean } \\
\text { Soyabean } \\
\text { Soyaboan }\end{array}$ & $\begin{array}{l}\frac{1}{1} \\
\frac{1}{1} \\
\frac{1}{1} \\
\frac{1}{1}\end{array}$ & $\begin{array}{r}0 \\
2 \\
4 \\
6 \\
8 \\
10 \\
15 \\
20\end{array}$ & $\begin{array}{l}D \\
B \\
D \\
B \\
E \\
D \\
D \\
C\end{array}$ & $\begin{array}{l}\mathrm{B} \\
\mathbf{Z} \\
\mathrm{D} \\
\mathrm{D} \\
\mathbf{E} \\
\mathbf{B} \\
\mathbf{T} \\
\mathbf{Z}\end{array}$ \\
\hline $\begin{array}{l}46 \\
47 \\
48 \\
49\end{array}$ & $\begin{array}{l}\text { Soyabean } \\
\text { Soyaboan } \\
\text { Soyabaan } \\
\text { Soyabean }\end{array}$ & $\begin{array}{l}2 \\
2 \\
2 \\
2\end{array}$ & $\begin{array}{l}2 \\
4 \\
6 \\
8\end{array}$ & $\begin{array}{l}D \\
C \\
D \\
C\end{array}$ & $\begin{array}{l}E \\
C \\
C \\
E\end{array}$ \\
\hline $\begin{array}{l}50 \\
51 \\
52 \\
53\end{array}$ & $\begin{array}{l}\text { Soyabean } \\
\text { Soyabean } \\
\text { Soyabean } \\
\text { Soyabaan }\end{array}$ & $\begin{array}{l}3 \\
3 \\
3 \\
3\end{array}$ & $\begin{array}{l}2 \\
4 \\
6 \\
8\end{array}$ & $\begin{array}{l}\mathrm{C} \\
\mathrm{A} \\
\mathrm{A} \\
\mathrm{A}\end{array}$ & $\begin{array}{l}C \\
C \\
D \\
B\end{array}$ \\
\hline $\begin{array}{l}54 \\
55 \\
56 \\
57\end{array}$ & $\begin{array}{l}\text { Linseed } \\
\text { Linseed } \\
\text { Inseed } \\
\text { Linseed }\end{array}$ & $\begin{array}{l}4 \\
4 \\
4 \\
4\end{array}$ & $\begin{array}{l}0 \\
2 \\
4 \\
6\end{array}$ & $\begin{array}{l}A \\
A \\
A \\
A\end{array}$ & $\begin{array}{l}\mathbf{B} \\
\mathbf{A} \\
\mathbf{A} \\
\mathbf{A}\end{array}$ \\
\hline $\begin{array}{l}58 \\
59 \\
60 \\
62\end{array}$ & $\begin{array}{l}\text { Porilia } \\
\text { Porilia } \\
\text { Pori11a } \\
\text { Porilia }\end{array}$ & $\begin{array}{l}5 \\
5 \\
5 \\
5\end{array}$ & $\begin{array}{l}0 \\
2 \\
4 \\
6\end{array}$ & $\begin{array}{l}\mathbf{B} \\
\mathbf{B} \\
\mathrm{A} \\
\mathrm{B}\end{array}$ & $\begin{array}{l}\mathbf{A} \\
\mathbf{B} \\
\mathbf{A} \\
\mathbf{A}\end{array}$ \\
\hline $\begin{array}{l}62 \\
63 \\
64 \\
65 \\
66\end{array}$ & $\begin{array}{l}\text { Soyabean } \\
\text { Soyabean } \\
\text { Soyabean } \\
\text { Soyabean } \\
\text { Soyaboan }\end{array}$ & $\begin{array}{l}6 \\
6 \\
6 \\
6 \\
6\end{array}$ & $\begin{array}{l}6 \\
6 \\
6 \\
6 \\
6\end{array}$ & $\begin{array}{l}B \\
C \\
C \\
B \\
B\end{array}$ & $\begin{array}{l}E \\
E \\
E \\
C \\
E\end{array}$ \\
\hline $\begin{array}{l}67 \\
68 \\
68\end{array}$ & $\begin{array}{l}\text { Commercla: } \\
\text { Commer } 1 \text { } \\
\text { Commerc } 1 \text { a. }\end{array}$ & $\begin{array}{l}\text { L Sample } \\
\text { I Sample } \\
\text { Lample }\end{array}$ & $\begin{array}{l}A \\
\mathrm{~B} \\
\mathrm{C}\end{array}$ & $\begin{array}{l}A \\
A \\
A\end{array}$ & $\begin{array}{l}\mathrm{A} \\
\mathrm{A} \\
\mathrm{A}\end{array}$ \\
\hline
\end{tabular}




\section{conctusIors}

It was at onee erident that the presenoe of ethyl dellulose was nelther benorioial or detrinontal to the 8108 of exterlor house paints. It was also orldent from a comparison of the first three series that it made very little differenee whether the 011 wes a light or heavy bodled one.

Howerer, upon comparing the three olle (sojabean, IInsed, and perille) against one another it was noted that there was a deolded difference among them, the perilia ofl being cuperlor to the I1nsed and the IInseed superior to the soprabean. Th1s was evidently the result of the indiridual onaracteristios of the olls themselves.

It was also noted that the topeoets were superlor in gloss to the primora. This was expected because of the lower pigment rolume ratio.

The gloss of the test peints compared ferorably with the comerolal samples considering the faot that there probably no sogabean oll in the latter. 
49.

PART III

PEATERATION 
THEORETICAL

The penotretion of a house primer may be derined as the degree of absorption of the rehlole by the surface upon which it is spread.

This property way be conveniently determinod by examining a thin crose soction of the primod wood under a mioroseope. The wood consists of a large number of oells surrounded by tiny caritios or canals all interconnected with one another. As the coating is applied to the aurface, the oll portion of the rehlele is absorbed by the wood and ponetrates to a dopth depending upon Its body or risooeity. A cortein depth of ponetretion ( 2 to 3 wood cells) is neceesery for good adhealon of the IIIm to the ourface. Bxoess penotration is not desirable because of the depletion of the ofl from the 1110 remsining on the surface.

The primers should have the seme plement voh10le ratio and should not contaln excess quantitios of thinner. The wood should be of the same type and should be as uniform and free from defoets as poesible. The moleture content is also important. 


\section{EXPERTMRATtal wORK}

A rather soft wood anoh as wite pine was used in determining the depth of penotration, in order to obtain a dosirablo section for examination. After wood of uniform quality and appearance was selooted. the primers were applied with a brush and allowed to ary. A thiz section was cut from the wood and examinod under a mloroseope by means of tranemitted 11ght. The depth of penotration into the wood ahowed up as a yellow encircling net of oll around the cells.

The results of the tests were reported in Table $X$ as the penetration in muber of wood calls from the surface. 
TABIE $x$

PEANETRATION OF ESTERIOR HOUSE PRIMERS

\begin{tabular}{|c|c|c|c|c|}
\hline No. & 011 & $\begin{array}{l}\text { Serios } \\
\text { Ho. }\end{array}$ & $\begin{array}{l}\text { Poroent } \\
\text { Ethooel }\end{array}$ & $\begin{array}{c}\text { Penetration in white Pine } \\
\text { No. of nood Celis }\end{array}$ \\
\hline $\begin{array}{l}1 \\
2 \\
3 \\
4 \\
5 \\
6 \\
7 \\
8\end{array}$ & $\begin{array}{l}\text { Soyabean } \\
\text { Soyabean } \\
\text { Soyabean } \\
\text { Soyabean } \\
\text { Sojaboan } \\
\text { Sojaboan } \\
\text { Soyabean } \\
\text { Soyabean }\end{array}$ & $\begin{array}{l}2 \\
1 \\
2 \\
1 \\
1 \\
1 \\
1 \\
1\end{array}$ & $\begin{array}{r}0 \\
2 \\
4 \\
6 \\
8 \\
10 \\
15 \\
20\end{array}$ & $\begin{array}{c}5 \\
3-4 \\
2 \\
1-2 \\
1 \\
2 \\
2 \\
2\end{array}$ \\
\hline $\begin{array}{r}9 \\
10 \\
11 \\
12\end{array}$ & $\begin{array}{l}\text { Soyabean } \\
\text { Soyaboan } \\
\text { Soyabean } \\
\text { Soyabean }\end{array}$ & $\begin{array}{l}2 \\
2 \\
2 \\
2\end{array}$ & $\begin{array}{l}2 \\
4 \\
6 \\
6\end{array}$ & $\begin{array}{l}3 \\
3 \\
2 \\
2\end{array}$ \\
\hline $\begin{array}{l}13 \\
14 \\
15 \\
16\end{array}$ & $\begin{array}{l}\text { Soyabean } \\
\text { Soyabean } \\
\text { Soyaboan } \\
\text { Soyabean }\end{array}$ & $\begin{array}{l}3 \\
3 \\
3 \\
3\end{array}$ & $\begin{array}{l}2 \\
4 \\
6 \\
8\end{array}$ & $\begin{array}{l}6-8 \\
6-8 \\
6-8 \\
6-8\end{array}$ \\
\hline $\begin{array}{l}17 \\
18 \\
18 \\
20\end{array}$ & $\begin{array}{l}\text { LInseed } \\
\text { Linseed } \\
\text { Linseed } \\
\text { Linseed }\end{array}$ & $\begin{array}{l}4 \\
4 \\
4 \\
4\end{array}$ & $\begin{array}{l}0 \\
2 \\
4 \\
6\end{array}$ & $\begin{array}{l}3-4 \\
2-3 \\
2-3 \\
2-3\end{array}$ \\
\hline $\begin{array}{l}21 \\
22 \\
23 \\
24\end{array}$ & $\begin{array}{l}\text { Porilia } \\
\text { Perilia } \\
\text { Perilla } \\
\text { Perilla }\end{array}$ & $\begin{array}{l}5 \\
5 \\
5 \\
5\end{array}$ & $\begin{array}{l}0 \\
2 \\
4 \\
6\end{array}$ & $\begin{array}{l}3-4 \\
2-3 \\
2-3 \\
2-3\end{array}$ \\
\hline $\begin{array}{l}25 \\
26 \\
27 \\
28 \\
29\end{array}$ & $\begin{array}{l}\text { Soyaboan } \\
\text { Soyabean } \\
\text { Soyaboan } \\
\text { Soyabean } \\
\text { Soyabean }\end{array}$ & $\begin{array}{l}8 \\
6 \\
6 \\
6 \\
6\end{array}$ & $\begin{array}{l}6 \\
6 \\
6 \\
6 \\
6\end{array}$ & $\begin{array}{c}1-2 \\
1 \\
1 \\
1 \\
1\end{array}$ \\
\hline $\begin{array}{l}30 \\
31 \\
32 \\
33 \\
34\end{array}$ & $\begin{array}{l}\text { Soyaboan } \\
\text { Soyaboan } \\
\text { Soyabean } \\
\text { IIngeod } \\
\text { Porilla }\end{array}$ & $\begin{array}{l}1 \\
1 \\
1 \\
4 \\
5\end{array}$ & $\begin{array}{r}2 \\
6 \\
10 \\
6 \\
6\end{array}$ & $\begin{array}{c}3 \\
2 \\
1 \\
2-3 \\
2-3\end{array}$ \\
\hline $\begin{array}{l}35 \\
36 \\
37\end{array}$ & $\begin{array}{l}\text { Commercia } \\
\text { Commerola } \\
\text { Comerola }\end{array}$ & $\begin{array}{l}1 \text { Sampl } \\
1 \text { Sampl } \\
1 \text { Sampl }\end{array}$ & $\begin{array}{l}\text { A } \\
\text { B } \\
\text { C }\end{array}$ & $\begin{array}{c}3 \\
2-3 \\
2-3\end{array}$ \\
\hline
\end{tabular}




\section{cancuosions}

The ethyl collulose content has a derinite effoct upon the penotration of wood primers. In praetioally all ceses the penetration deoreased as the cellulose content 1noressed. As in other cases, this wes probably caused by the bodying effeot upon the oll, the heavier bodied olla penetrating to a losser degree. The high penetration of the third serles was probably caused by the unbodied o1l used in the preparation of the samples in this series. The peroent of -thyl cellulose present had little or no effect as was eridoneed by the equivelent penotration of the four samples.

There was very little difference ahown by a change in oll composition, but the ethyl cellulose seomed to have greater ratarding affect upon the soyabean then on ofther the linseed or perilla olls.

The stage of cooking the ethyl collulose in the oll had little effect upon the penetration as shown by the samples of serles $81 x$.

The penotration of the test paints compared farorably with the commeroiel samples. 
54.

PARI IV

BROSHABILITX 
THRORETICAI

Brushablilty may be defined as the ease of application of a protective coating upon a surface by moans or a brush.

Op to the present time no simple and sccurate means has been derised for determining the degree of brushablitity of an exterior paint. The common method in use today is a practical test whioh consists of brushIng a sample on test surface and noting suoh properties as the drag of the brush, the ebility of the paint to flow from the brush and wet the surface and so forth. This property is very diffloult to judge even when carried out by an experienced operator. The determination exhibits the disadrantage of belng dependent upon the mental vigor, or state of tiredness of the painter. Wlth paints conteining large percentages of easily rolatile solvents, the diffloulty of effecting sultable comparisons of various paints 18 particularly pronounced (12). Types and conditions of both brushes and surfaces are important factors. 
The degres of brushability was noted in the preparation of the panels for exposure data. For further Information reference should be made to the section on Weatherability.

The results of the tests were reported in rables $\mathrm{XI}$ and $\mathrm{XI}$ as haring ratings of exoellent, rory good, good, falr, or poor depending upon such properties as those previously listed. 
TABLE XI

BRUSHABIIIIT OF EXTERIOR HOUSE PRIMERS

\begin{tabular}{|c|c|c|c|c|c|}
\hline No. & 011 & $\begin{array}{c}\text { Ser1e* } \\
\text { Ho. }\end{array}$ & $\begin{array}{l}\text { Percent } \\
\text { Ethocel }\end{array}$ & \multicolumn{2}{|c|}{ Rating } \\
\hline $\begin{array}{l}1 \\
2 \\
3 \\
4 \\
5 \\
6 \\
7 \\
8\end{array}$ & $\begin{array}{l}\text { Soyabean } \\
\text { Soyaboan } \\
\text { Soyabaan } \\
\text { Soyabean } \\
\text { Soyabean } \\
\text { Soyabean } \\
\text { Soyaboan } \\
\text { Soyabean }\end{array}$ & $\begin{array}{l}1 \\
1 \\
1 \\
1 \\
2 \\
1 \\
1 \\
1\end{array}$ & $\begin{array}{r}0 \\
2 \\
4 \\
6 \\
8 \\
10 \\
15 \\
20\end{array}$ & $\begin{array}{l}\text { Poor } \\
\text { Fair } \\
\text { Good } \\
\text { Good } \\
\text { Good } \\
\text { Good } \\
\text { Good } \\
\text { Good }\end{array}$ & \\
\hline $\begin{array}{r}9 \\
10 \\
11 \\
12\end{array}$ & $\begin{array}{l}\text { Soyabean } \\
\text { Soyabean } \\
\text { Soyabean } \\
\text { Soyabean }\end{array}$ & $\begin{array}{l}2 \\
2 \\
2 \\
2\end{array}$ & $\begin{array}{l}8 \\
4 \\
6 \\
8\end{array}$ & $\begin{array}{l}\text { Very } \\
\text { Vory } \\
\text { Vory } \\
\text { Vory }\end{array}$ & $\begin{array}{l}\text { Good } \\
\text { Good } \\
\text { Good } \\
\text { Gcod }\end{array}$ \\
\hline $\begin{array}{l}13 \\
14 \\
15 \\
16\end{array}$ & $\begin{array}{l}\text { Soyabean } \\
\text { Soyabean } \\
\text { Soyabean } \\
\text { Soyaboan }\end{array}$ & $\begin{array}{l}3 \\
3 \\
3 \\
3\end{array}$ & $\begin{array}{l}2 \\
4 \\
6 \\
8\end{array}$ & $\begin{array}{l}\text { Fair } \\
\text { Fair } \\
\text { Fair } \\
\text { Fair }\end{array}$ & \\
\hline $\begin{array}{l}17 \\
18 \\
18 \\
20\end{array}$ & $\begin{array}{l}\text { Linseed } \\
\text { LInseed } \\
\text { Linseed } \\
\text { Linseed }\end{array}$ & $\begin{array}{l}4 \\
4 \\
4\end{array}$ & $\begin{array}{l}0 \\
2 \\
4 \\
6\end{array}$ & $\begin{array}{l}\text { Fair } \\
\text { cood } \\
\text { Good } \\
\text { Feir }\end{array}$ & \\
\hline $\begin{array}{l}21 \\
22 \\
23 \\
24\end{array}$ & $\begin{array}{l}\text { Porilla } \\
\text { Perilla } \\
\text { Perilla } \\
\text { Perilia }\end{array}$ & $\begin{array}{l}5 \\
5 \\
5 \\
5\end{array}$ & $\begin{array}{l}0 \\
2 \\
4 \\
6\end{array}$ & $\begin{array}{l}\text { Fair } \\
\text { Good } \\
\text { Good } \\
\text { Good }\end{array}$ & \\
\hline $\begin{array}{l}25 \\
26 \\
27 \\
28 \\
28\end{array}$ & $\begin{array}{l}\text { Soyabean } \\
\text { Soyabean } \\
\text { Soyabean } \\
\text { Soyabean } \\
\text { Soyaboan }\end{array}$ & $\begin{array}{l}6 \\
6 \\
6 \\
6 \\
6\end{array}$ & $\begin{array}{l}6 \\
6 \\
6 \\
6 \\
6\end{array}$ & $\begin{array}{l}\text { Poor } \\
\text { Poor } \\
\text { Falr } \\
\text { Fair } \\
\text { Falr }\end{array}$ & \\
\hline $\begin{array}{l}30 \\
31 \\
32 \\
33\end{array}$ & $\begin{array}{l}\text { Soyabean } \\
\text { Soyabean } \\
\text { Soyabean } \\
\text { Inseed } \\
\text { Perilla }\end{array}$ & $\begin{array}{l}1 \\
\frac{1}{1} \\
4 \\
5\end{array}$ & $\begin{array}{r}2 \\
6 \\
10 \\
6 \\
6\end{array}$ & $\begin{array}{l}\text { Exoe1 } \\
\text { Exoe1 } \\
\text { Exce1 } \\
\text { Exoe1 } \\
\text { Exoel }\end{array}$ & $\begin{array}{l}\text { Lent } \\
\text { Lient } \\
\text { Lient } \\
\text { Lient } \\
\text { Llent }\end{array}$ \\
\hline $\begin{array}{l}36 \\
36\end{array}$ & $\begin{array}{l}\text { Commero i } \\
\text { Commero is } \\
\text { Commerc1 }\end{array}$ & $\begin{array}{l}\text { Sample } \\
\text { Sample } \\
\text { Sample }\end{array}$ & $\begin{array}{l}\mathrm{A} \\
\mathrm{B} \\
\mathrm{C}\end{array}$ & $\begin{array}{l}\text { Very } \\
\text { Very } \\
\text { Good }\end{array}$ & $\begin{array}{l}\text { Good } \\
\text { Good }\end{array}$ \\
\hline
\end{tabular}

* Refer to Table III 
BRUSHABILITY OF DXTERIOR HOUSE TOPCOATS

\begin{tabular}{|c|c|c|c|c|c|}
\hline No. & 011 & $\begin{array}{c}\text { Serles } \\
\text { No. }\end{array}$ & $\begin{array}{l}\text { Porcent } \\
\text { Bthooel }\end{array}$ & Rat1n & \\
\hline $\begin{array}{l}38 \\
38 \\
40 \\
41 \\
42 \\
43 \\
44 \\
45\end{array}$ & $\begin{array}{l}\text { Soyabean } \\
\text { Sojabean } \\
\text { Soyabean } \\
\text { Soyabean } \\
\text { Soyabean } \\
\text { Soyabean } \\
\text { Soyabean } \\
\text { Soyabean }\end{array}$ & $\begin{array}{l}1 \\
1 \\
1 \\
1 \\
1 \\
1 \\
1 \\
1\end{array}$ & $\begin{array}{r}0 \\
2 \\
4 \\
6 \\
8 \\
10 \\
15 \\
20\end{array}$ & $\begin{array}{l}\text { Poor } \\
\text { Pair } \\
\text { Good } \\
\text { Good } \\
\text { cood } \\
\text { Good } \\
\text { Good } \\
\text { rair }\end{array}$ & \\
\hline $\begin{array}{l}46 \\
47 \\
48 \\
40\end{array}$ & $\begin{array}{l}\text { Soyabean } \\
\text { Soyabean } \\
\text { Soyabean } \\
\text { Soyabean }\end{array}$ & $\begin{array}{l}2 \\
2 \\
2 \\
2\end{array}$ & $\begin{array}{l}2 \\
4 \\
6 \\
8\end{array}$ & $\begin{array}{l}\text { Very } \\
\text { Very } \\
\text { Very } \\
\text { Very }\end{array}$ & $\begin{array}{l}\text { Good } \\
\text { Good } \\
\text { Good } \\
\text { Good }\end{array}$ \\
\hline $\begin{array}{l}50 \\
51 \\
52 \\
53\end{array}$ & $\begin{array}{l}\text { Soyabean } \\
\text { Soyabean } \\
\text { Soyabean } \\
\text { Soyabean }\end{array}$ & $\begin{array}{l}3 \\
3 \\
3 \\
3\end{array}$ & $\begin{array}{l}2 \\
4 \\
6 \\
8\end{array}$ & $\begin{array}{l}\text { Pair } \\
\text { Pair } \\
\text { Fair } \\
\text { Pair }\end{array}$ & \\
\hline $\begin{array}{l}54 \\
55 \\
56 \\
57\end{array}$ & $\begin{array}{l}\text { LInseed } \\
\text { LInseed } \\
\text { Linseed } \\
\text { Linseed }\end{array}$ & $\begin{array}{l}4 \\
4 \\
4 \\
4\end{array}$ & $\begin{array}{l}0 \\
2 \\
4 \\
6\end{array}$ & $\begin{array}{l}\text { Pair } \\
\text { Good } \\
\text { Good } \\
\text { Good }\end{array}$ & \\
\hline $\begin{array}{l}58 \\
59 \\
60 \\
61\end{array}$ & $\begin{array}{l}\text { Peri11a } \\
\text { Peri11a } \\
\text { Por } 111 a \\
\text { Peri11a }\end{array}$ & $\begin{array}{l}5 \\
5 \\
5 \\
5\end{array}$ & $\begin{array}{l}0 \\
2 \\
4 \\
6\end{array}$ & $\begin{array}{l}\text { Palr } \\
\text { Good } \\
\text { Good } \\
\text { Good }\end{array}$ & \\
\hline $\begin{array}{l}62 \\
63 \\
64 \\
65 \\
66\end{array}$ & $\begin{array}{l}\text { Soyabean } \\
\text { Soyabean } \\
\text { Soyabean } \\
\text { Soyabean } \\
\text { Soyabean }\end{array}$ & $\begin{array}{l}6 \\
6 \\
6 \\
6 \\
6\end{array}$ & $\begin{array}{l}6 \\
6 \\
6 \\
6 \\
6\end{array}$ & $\begin{array}{l}\text { Poor } \\
\text { Poor } \\
\text { Poor } \\
\text { ralr } \\
\text { Fa1r }\end{array}$ & \\
\hline $\begin{array}{l}67 \\
68 \\
69\end{array}$ & $\begin{array}{l}\text { Commercio } \\
\text { Commercia } \\
\text { Commercie }\end{array}$ & $\begin{array}{l}1 \text { Sample } \\
1 \text { Sample } \\
1 \text { Samplo }\end{array}$ & $\begin{array}{l}A \\
\text { C } \\
\text { C }\end{array}$ & $\begin{array}{l}\text { Good } \\
\text { Very } \\
\text { Very }\end{array}$ & $\begin{array}{l}\text { Good } \\
\text { Good }\end{array}$ \\
\hline
\end{tabular}


COMCLUSIORS

The bruabability of the saples after thinning Increased with an Inorease in ethyl cellulose content. Howerer, before thlaning it way be sald that tho brushability decreased with an inorease in the percentage of the cellulose derlvatire because of the inoreased body of the 011. A possible exoeption were those palnts oontaining no ethyl cellulose. As a certain amount of body 1. nocessary for good bruahing propertios, a small peroent of ethyl cellulose is benerlolel. This explains the faot that the paints in serles two had the same brushab1lity and were better than those in series three. The aluminum palnte were auperior to all the others in bruahability beoause of the learing offoot of the plement inrolred.

In genoral the brushabilities of the commerolal paints were bettor than the test samples because of proper rehlele formulations. 
60.

PART 7

LEVEITIO 


\section{THEORETICAL}

Loveling may be defined as the ability of a freshly applied coating to produce a smooth, level surfaoe from an 1rregular one.

The simplest moth in use is by the obserration of the smoothness of the $112 \mathrm{~m}$ when dry.

The results obtained depend upon the degree of brushing and the stiffnoss of the brush as well as the type and condition of the surface. In the oase of aprayed coatings, the results depend upon pressure, type of nozzle, and other factors (3). 


\section{DCPERTYEXTAL FORR}

The amount of leveling produced by the rarious paints was obtalned by observing the anoothnese of the flim applied for the determination of the degree of brushab111ty.

The results of the tests were reported in Tables XII and IV as having ratings of rery good. good. ralr, poor, or very poor depending upon the apparent enoothneas. 


\begin{tabular}{|c|c|c|c|c|}
\hline No. & 011 & $\begin{array}{c}\text { Serfos } \\
\text { No. }\end{array}$ & $\begin{array}{l}\text { Percent } \\
\text { Ethocel }\end{array}$ & Rating \\
\hline $\begin{array}{l}1 \\
2 \\
3 \\
4 \\
5 \\
6 \\
7 \\
8\end{array}$ & $\begin{array}{l}\text { Soyabean } \\
\text { Soyabean } \\
\text { Soyabean } \\
\text { Soyabean } \\
\text { Soyaboan } \\
\text { Soraban } \\
\text { Soyabean } \\
\text { Soyabean }\end{array}$ & $\begin{array}{l}1 \\
1 \\
1 \\
1 \\
1 \\
1 \\
1 \\
1\end{array}$ & $\begin{array}{r}0 \\
2 \\
4 \\
6 \\
8 \\
10 \\
15 \\
20\end{array}$ & $\begin{array}{l}\text { Vory Poor } \\
\text { Poor } \\
\text { Poor } \\
\text { Fair } \\
\text { Fair } \\
\text { Good } \\
\text { Good } \\
\text { Good }\end{array}$ \\
\hline $\begin{array}{l}9 \\
10 \\
11 \\
12\end{array}$ & $\begin{array}{l}\text { Joyabean } \\
\text { Soyabean } \\
\text { Soyabean } \\
\text { Soyabean }\end{array}$ & $\begin{array}{l}2 \\
2 \\
2 \\
2\end{array}$ & $\begin{array}{l}2 \\
4 \\
6 \\
8\end{array}$ & $\begin{array}{l}\text { Good } \\
\text { Good } \\
\text { Good } \\
\text { Good }\end{array}$ \\
\hline $\begin{array}{l}13 \\
14 \\
15 \\
16\end{array}$ & $\begin{array}{l}\text { Soyabean } \\
\text { Soyabean } \\
\text { Soyabean } \\
\text { Soyabean }\end{array}$ & $\begin{array}{l}3 \\
3 \\
3 \\
3\end{array}$ & $\begin{array}{l}2 \\
4 \\
6 \\
8\end{array}$ & $\begin{array}{l}\text { Fair } \\
\text { Fair } \\
\text { Pair } \\
\text { Fair }\end{array}$ \\
\hline $\begin{array}{l}17 \\
18 \\
19 \\
20\end{array}$ & $\begin{array}{l}\text { Inseed } \\
\text { LInseed } \\
\text { LInseed } \\
\text { Linseed }\end{array}$ & $\begin{array}{l}4 \\
4 \\
4 \\
4\end{array}$ & $\begin{array}{l}0 \\
2 \\
4 \\
6\end{array}$ & $\begin{array}{l}\text { Poor } \\
\text { Fair } \\
\text { Fair } \\
\text { Pair }\end{array}$ \\
\hline $\begin{array}{l}21 \\
22 \\
23 \\
24\end{array}$ & $\begin{array}{l}\text { Perilla } \\
\text { Perilia } \\
\text { Perilia } \\
\text { Perilla }\end{array}$ & $\begin{array}{l}5 \\
5 \\
5 \\
5\end{array}$ & $\begin{array}{l}0 \\
2 \\
4 \\
6\end{array}$ & $\begin{array}{l}\text { Falr } \\
\text { Fair } \\
\text { Cood } \\
\text { cood }\end{array}$ \\
\hline $\begin{array}{l}25 \\
26 \\
29 \\
28 \\
29\end{array}$ & $\begin{array}{l}\text { Soyabean } \\
\text { Soyabean } \\
\text { Soyabean } \\
\text { Soyabean } \\
\text { Soyabean }\end{array}$ & $\begin{array}{l}6 \\
6 \\
6 \\
6 \\
6\end{array}$ & $\begin{array}{l}6 \\
5 \\
6 \\
6 \\
6\end{array}$ & $\begin{array}{l}\text { Poor } \\
\text { Fair } \\
\text { Pair } \\
\text { Fair } \\
\text { Pair }\end{array}$ \\
\hline $\begin{array}{l}35 \\
36 \\
37\end{array}$ & $\begin{array}{l}\text { Commercia } \\
\text { Commorcia } \\
\text { Commerola. }\end{array}$ & $\begin{array}{ll}1 & \text { Samplo } \\
1 & \text { Semplo } \\
1 & \text { Sample }\end{array}$ & $\begin{array}{l}A \\
B \\
C\end{array}$ & $\begin{array}{l}\text { Good } \\
\text { Vory Good } \\
\text { Fair }\end{array}$ \\
\hline
\end{tabular}


LEVETIHG OY EXTERTOR HOUSE TOPCOATS

\begin{tabular}{|c|c|c|c|c|}
\hline No. & 011 & $\begin{array}{c}\text { Ser10* } \\
\text { No. }\end{array}$ & $\begin{array}{l}\text { Peroont } \\
\text { Ethooel }\end{array}$ & Rating \\
\hline $\begin{array}{l}38 \\
39 \\
40 \\
41 \\
42 \\
43 \\
44 \\
45\end{array}$ & $\begin{array}{l}\text { Soyabean } \\
\text { Soyabean } \\
\text { Soyabenn } \\
\text { Soyabean } \\
\text { Soyabean } \\
\text { Sojabean } \\
\text { Sojabean } \\
\text { Soyaboan }\end{array}$ & $\begin{array}{l}1 \\
2 \\
1 \\
1 \\
1 \\
1 \\
1 \\
1\end{array}$ & $\begin{array}{r}0 \\
2 \\
4 \\
6 \\
8 \\
10 \\
15 \\
20\end{array}$ & $\begin{array}{l}\text { Poor } \\
\text { rair } \\
\text { Fair } \\
\text { Fair } \\
\text { Cood } \\
\text { Good } \\
\text { Cood } \\
\text { Good }\end{array}$ \\
\hline $\begin{array}{l}46 \\
47 \\
48 \\
49\end{array}$ & $\begin{array}{l}\text { Soyabean } \\
\text { Soraboan } \\
\text { Soyaboan } \\
\text { Soyaboan }\end{array}$ & $\begin{array}{l}2 \\
2 \\
2 \\
2\end{array}$ & $\begin{array}{l}2 \\
4 \\
6 \\
8\end{array}$ & $\begin{array}{l}\text { Gond } \\
\text { Good } \\
\text { Good } \\
\text { Good }\end{array}$ \\
\hline $\begin{array}{l}50 \\
51 \\
52 \\
53\end{array}$ & $\begin{array}{l}\text { Sojabean } \\
\text { Sojabean } \\
\text { Sojabean } \\
\text { Sojaboan }\end{array}$ & $\begin{array}{l}3 \\
3 \\
3 \\
3\end{array}$ & $\begin{array}{l}2 \\
4 \\
6 \\
8\end{array}$ & $\begin{array}{l}\text { Fair } \\
\text { Fair } \\
\text { Cood } \\
\text { Cood }\end{array}$ \\
\hline $\begin{array}{l}54 \\
55 \\
56 \\
57\end{array}$ & $\begin{array}{l}\text { Linseed } \\
\text { IInseed } \\
\text { IInseed } \\
\text { Linseed }\end{array}$ & $\begin{array}{l}4 \\
4 \\
4\end{array}$ & $\begin{array}{l}0 \\
2 \\
4 \\
6\end{array}$ & $\begin{array}{l}\text { Talr } \\
\text { Good } \\
\text { Cood } \\
\text { Good }\end{array}$ \\
\hline $\begin{array}{l}58 \\
59 \\
60 \\
61\end{array}$ & $\begin{array}{l}\text { Perilla } \\
\text { Perilia } \\
\text { Perilia } \\
\text { Perilia }\end{array}$ & $\begin{array}{l}5 \\
5 \\
5 \\
5\end{array}$ & $\begin{array}{l}0 \\
2 \\
4 \\
6\end{array}$ & $\begin{array}{l}\text { Yaix } \\
\text { Cood } \\
\text { Good } \\
\text { Good }\end{array}$ \\
\hline $\begin{array}{l}62 \\
63 \\
64 \\
65 \\
66\end{array}$ & $\begin{array}{l}\text { Soyabean } \\
\text { Sojabean } \\
\text { Soyabean } \\
\text { Sorabean } \\
\text { Soyabean }\end{array}$ & $\begin{array}{l}6 \\
6 \\
6 \\
6 \\
6\end{array}$ & $\begin{array}{l}6 \\
6 \\
6 \\
6 \\
6\end{array}$ & $\begin{array}{l}\text { rair } \\
\text { Fair } \\
\text { Fair } \\
\text { Oood } \\
\text { Cood }\end{array}$ \\
\hline $\begin{array}{l}67 \\
68 \\
68\end{array}$ & $\begin{array}{l}\text { Commorolad } \\
\text { Commorola] } \\
\text { Commerole. }\end{array}$ & $\begin{array}{l}\text { Samplo } \\
\text { Samplo } \\
\text { Samplo }\end{array}$ & $\begin{array}{l}\mathbf{A} \\
\mathbf{B} \\
\mathbf{C}\end{array}$ & $\begin{array}{l}\text { Good } \\
\text { Very Good } \\
\text { Very Good }\end{array}$ \\
\hline
\end{tabular}




\section{Conclusians}

Fran a comparison of the results obtalned, an Increase in ethyl cellulose content definitely produced better 1evel1ng. This was undoubtediy caused by the bodying efreat of the celluloee upon the oll, sines a bodled 011 will usuelly produce a smoother aurface when combined with a plgment than an unbodied one. This offect was shown again apon comparing series two with serles three.

In general, the olls Inoreased in thelr 1eveling properties from soyabean through Ilnseed to perilla. The topeoets leveled somowhet botter than the primers but not to any great extent. This was traced to tho lower plement volume ratio of the former. As a wole the oomorelal paints were much better, as regards leveling, than the test samples. Th1s may be attributed to the proper rehlole formulatlons of the former. 
68.

PART VI

SACGING 
THEORETICAI

The purpose of the sagging test is to determine the ability of the paint film to romain evenly apread over a vertioel surface without "running" or "streaking".

A almple mathod or testing consists of brushIng the paint on a wotal panel whioh is stood in a vertical position until dry.

The results of this teat depend in a large degree upon the oonsistenoy or risoosity of the paint as well as the quantity appliod to the surface and the mothod of appliostion. Types and oonditions of surfaces also hare a noticeable effeot. 


\section{EXPEKIMENTAL :ORK}

It was declded to use metal panels in conductIng this test, for the tendency of the paint to sag wes much greater than on wood hecause of the difference in the type of surface. The panels were of "sort" steel, 5 inches long and 3 inches wide. They were thoroughly cleaned with toluol before coating.

The paint was brished along the length, the upper half of the panel then belng brushed along the width so that the brush marks were horizontal when the panel was stood on the short end. The panel was allowed to remein vertical until the film had dried. The results of the tests were reported in Tables XV and XVI as passing or falling. 


\begin{tabular}{|c|c|c|c|c|}
\hline No. & 012 & $\begin{array}{c}\text { Serie } \\
\text { Ho. }\end{array}$ & $\begin{array}{l}\text { Percent } \\
\text { Bthooel }\end{array}$ & Rating \\
\hline $\begin{array}{l}1 \\
8 \\
3 \\
4 \\
5 \\
6 \\
7 \\
8\end{array}$ & $\begin{array}{l}\text { Seyabean } \\
\text { Seyabean } \\
\text { Seyabean } \\
\text { Sejabean } \\
\text { Soynbean } \\
\text { Soyaboan } \\
\text { Sojabean } \\
\text { Sornbean }\end{array}$ & $\begin{array}{l}\frac{1}{1} \\
\frac{1}{1} \\
\frac{1}{1} \\
\frac{1}{1}\end{array}$ & $\begin{array}{r}0 \\
2 \\
4 \\
6 \\
8 \\
10 \\
15 \\
20\end{array}$ & $\begin{array}{l}\text { Passed } \\
\text { Passed } \\
\text { Pussed } \\
\text { Passed } \\
\text { Pessed } \\
\text { Paseed } \\
\text { Parsed } \\
\text { Pasped }\end{array}$ \\
\hline $\begin{array}{r}9 \\
10 \\
11 \\
12\end{array}$ & $\begin{array}{l}\text { Soyrabean } \\
\text { Soyabean } \\
\text { Soyabean } \\
\text { Soyabean }\end{array}$ & $\begin{array}{l}2 \\
2 \\
2 \\
2\end{array}$ & $\begin{array}{l}2 \\
4 \\
6 \\
8\end{array}$ & $\begin{array}{l}\text { Passe } \\
\text { Passo } \\
\text { Passo } \\
\text { Passo }\end{array}$ \\
\hline $\begin{array}{l}13 \\
14 \\
15 \\
16\end{array}$ & $\begin{array}{l}\text { Soyabean } \\
\text { Soyabean } \\
\text { Soytabean } \\
\text { Soyabean }\end{array}$ & $\begin{array}{l}3 \\
3 \\
3 \\
3\end{array}$ & $\begin{array}{l}2 \\
4 \\
6 \\
8\end{array}$ & $\begin{array}{l}\text { Passed } \\
\text { Pussed } \\
\text { Peseed }\end{array}$ \\
\hline $\begin{array}{l}17 \\
18 \\
19 \\
20\end{array}$ & $\begin{array}{l}\text { Linseed } \\
\text { Linseed } \\
\text { LInseed } \\
\text { Limpoed }\end{array}$ & $\begin{array}{l}4 \\
4 \\
4\end{array}$ & $\begin{array}{l}0 \\
2 \\
4 \\
6\end{array}$ & $\begin{array}{l}\text { Paese } \\
\text { Passe } \\
\text { Passe } \\
\text { Parse }\end{array}$ \\
\hline $\begin{array}{l}21 \\
22 \\
23 \\
24\end{array}$ & $\begin{array}{l}\text { Per111a } \\
\text { Per111a } \\
\text { Per } 111 a \\
\text { Per111a }\end{array}$ & $\begin{array}{l}\mathbf{5} \\
5 \\
5 \\
5\end{array}$ & $\begin{array}{l}0 \\
2 \\
4 \\
6\end{array}$ & $\begin{array}{l}\text { Passo } \\
\text { Passe } \\
\text { Pasao }\end{array}$ \\
\hline $\begin{array}{l}25 \\
26 \\
27 \\
80 \\
80\end{array}$ & 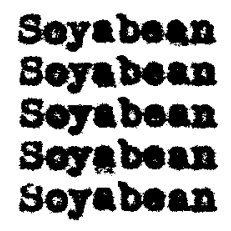 & $\begin{array}{l}6 \\
6 \\
6 \\
6 \\
6\end{array}$ & $\begin{array}{l}6 \\
6 \\
6 \\
6 \\
6\end{array}$ & $\begin{array}{l}\text { Passo } \\
\text { Paseo } \\
\text { Pnseo } \\
\text { Paseo } \\
\text { Pas8o }\end{array}$ \\
\hline $\begin{array}{l}35 \\
36 \\
37\end{array}$ & $\begin{array}{l}\text { Commorol } \\
\text { Cammero } \\
\text { Gemmerole }\end{array}$ & $\begin{array}{l}\text { Sample } \\
\text { Sample } \\
\text { Sample }\end{array}$ & $\begin{array}{l}\mathbf{A} \\
\mathbf{B}\end{array}$ & $\begin{array}{l}\text { Pesso } \\
\text { Yese } \\
\text { Yasse }\end{array}$ \\
\hline
\end{tabular}


TABLE XVI

SAGCDIG OF EXTERIOR HOUSR TOPCOATS

\begin{tabular}{|c|c|c|c|c|}
\hline No. & 011 & $\begin{array}{c}\text { sories } \\
\text { Ho. }\end{array}$ & $\begin{array}{l}\text { Peroent } \\
\text { Ethoeel }\end{array}$ & Eating \\
\hline $\begin{array}{l}38 \\
39 \\
40 \\
41 \\
42 \\
43 \\
44 \\
45\end{array}$ & $\begin{array}{l}\text { Soyaboan } \\
\text { Soyabean } \\
\text { Soyabean } \\
\text { Soyabean } \\
\text { Soybbean } \\
\text { Soyabean } \\
\text { Soyabean } \\
\text { Soymbean }\end{array}$ & $\begin{array}{l}\frac{1}{1} \\
1 \\
1 \\
1 \\
1 \\
\frac{1}{1}\end{array}$ & $\begin{array}{r}0 \\
2 \\
4 \\
6 \\
8 \\
10 \\
15 \\
20\end{array}$ & $\begin{array}{l}\text { Passed } \\
\text { Passed } \\
\text { Passed } \\
\text { Passed } \\
\text { Pailed } \\
\text { Passed } \\
\text { Parsed } \\
\text { Peraed }\end{array}$ \\
\hline $\begin{array}{l}46 \\
47 \\
48 \\
49\end{array}$ & $\begin{array}{l}\text { Soyaboan } \\
\text { Soyabean } \\
\text { Sojabean } \\
\text { Soyabean }\end{array}$ & $\begin{array}{l}2 \\
2 \\
2 \\
2\end{array}$ & $\begin{array}{l}2 \\
4 \\
6 \\
8\end{array}$ & $\begin{array}{l}\text { Felled } \\
\text { Falled } \\
\text { Fa11ed } \\
\text { Perned }\end{array}$ \\
\hline $\begin{array}{l}50 \\
51 \\
59 \\
53\end{array}$ & $\begin{array}{l}\text { Soyaboan } \\
\text { Soyabean } \\
\text { joyaboan } \\
\text { Soymbean }\end{array}$ & $\begin{array}{l}3 \\
3 \\
3 \\
3\end{array}$ & $\begin{array}{l}2 \\
4 \\
6 \\
6\end{array}$ & $\begin{array}{l}\text { Pussed } \\
\text { Puesed } \\
\text { Puesed } \\
\text { Presed }\end{array}$ \\
\hline $\begin{array}{l}54 \\
55 \\
56 \\
57\end{array}$ & $\begin{array}{l}\text { Linseed } \\
\text { IInseed } \\
\text { IInseed } \\
\text { IInsesd }\end{array}$ & $\begin{array}{l}4 \\
4 \\
4\end{array}$ & $\begin{array}{l}0 \\
2 \\
4 \\
6\end{array}$ & $\begin{array}{l}\text { Pasbod } \\
\text { Yereed } \\
\text { Paesed } \\
\text { Pusaed }\end{array}$ \\
\hline $\begin{array}{l}58 \\
59 \\
60 \\
61\end{array}$ & $\begin{array}{l}\text { Peri11a } \\
\text { Peri11a } \\
\text { Pari11a } \\
\text { Per111a }\end{array}$ & $\begin{array}{l}5 \\
5 \\
5 \\
5\end{array}$ & $\begin{array}{l}0 \\
2 \\
4 \\
6\end{array}$ & $\begin{array}{l}\text { Paseod } \\
\text { Paseed } \\
\text { Passed } \\
\text { Passed }\end{array}$ \\
\hline $\begin{array}{l}62 \\
63 \\
64 \\
65\end{array}$ & $\begin{array}{l}\text { Soynbean } \\
\text { Sorabean } \\
\text { soybbean } \\
\text { Bojabenn } \\
\text { Soraboan }\end{array}$ & $\begin{array}{l}6 \\
6 \\
6 \\
6 \\
6\end{array}$ & $\begin{array}{l}6 \\
6 \\
6 \\
6 \\
6\end{array}$ & $\begin{array}{l}\text { Passed } \\
\text { Passed } \\
\text { Passed } \\
\text { Passed } \\
\text { Passed }\end{array}$ \\
\hline $\begin{array}{l}67 \\
68\end{array}$ & $\begin{array}{l}\text { Commere } \\
\text { Combroro } \\
\text { Commero }\end{array}$ & $\begin{array}{l}\text { Sermple } \\
\text { Semplo } \\
\text { Serple }\end{array}$ & $\begin{array}{l}\mathbf{A} \\
\mathbf{B} \\
\mathbf{C}\end{array}$ & $\begin{array}{l}\text { Passe } \\
\text { Pasae } \\
\text { Pasee }\end{array}$ \\
\hline
\end{tabular}


CONCLUSIONS

It w1Il be noted that of all the samples tested, onif four showed signs of sagging and these were not extreme. Cheoks were run to deteralne whether the results would be inconsistent, but this wes not found to be the case. There was an apparent reason for the three samples of series two to sag. Thlo was traoed to the body of the original olls and the very lergo amounts of thinner required to bring these samples within the required visoosity range - the ratio of oll to thinner being $0.95,0.98$, and 1.29 respectively for the 2\%, 1\%, and 6\% samples. Also since these samples were topcoats, the lower pigment volume ratio would help to explain the fa1lure.

It was ovident thet the othyl celluloso content had 11ttlo erfect upon the sagging characteristios. 
78.

PART VII

HARDNLSS OR TACK 
THEORETICAI

The tack or hardness of a paint film from the time of epplieation to the time of complete drynese mey be taken as a measure of tho oxidation that has taken place while the film has been exposed to the alr.

A convenient instrument for meesuring this property is the Sward Hardness Rocker (PIB. 4). This Instrument asures the relatire hardness of a $511 \mathrm{~m}$, considering the hardness of pollshed plate glass as $100 \%$. The rocker consists essentially of a pair of ciroular bronze rings four inchos in diameter and spaoed one lnoh apart. The peripherles of the rockers are turned down on a radus of $0.5 \mathrm{~mm}$. Contained between the rookers are two small epirit lorels which are arbitrarily sot at the polnt where the rocker completes its fiftioth complote osoillation on polished plate glass. Class as the standard becomes $100 \%$ by multiplying the 50 oscillations by 2 . Values for other materlals are expressed in percent hardness by mitiplying the number of oscillations on their surfaces by 2 .

The flims must be equal in thickness, must be fres of dirt and Irregularities, and the tests should be conducted at a constant temperature and humidity. 


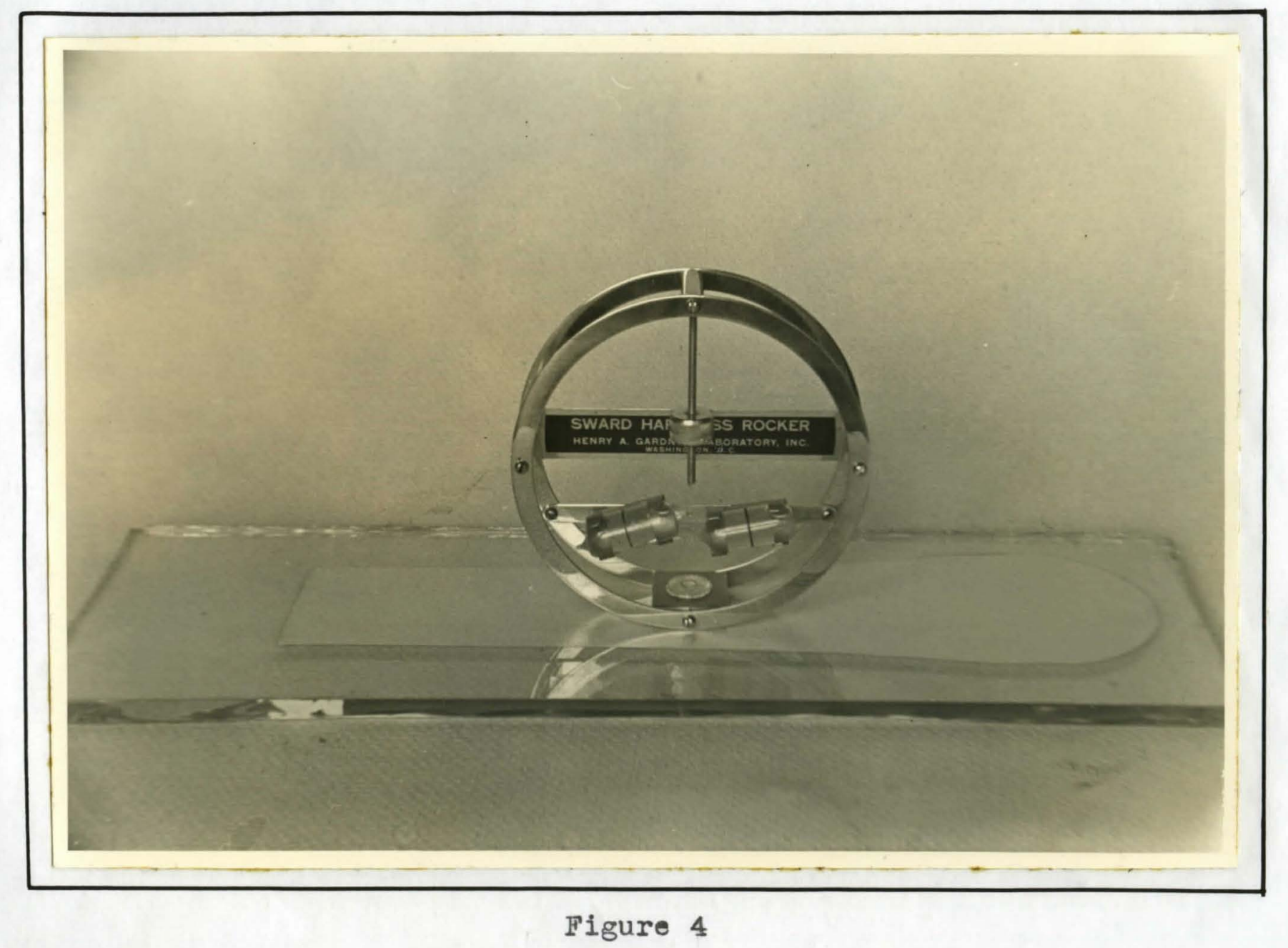

Sward Hardness Rocker 


\section{BXPERIMENTAI MORK}

It was first necessary to prepare films of the paints whose hardness it was desired to determine. This was accomplishod by casting films of the same thlokness with a Dow Filmograph on plate gless panel previously cleaned with toluol. By actual measurement the flims cast were $0.003 \pm 0.0005$ inches thlck. The Sward Rocker was adjusted to 50 oscillations on polished plate slass, fter which a hercness or tack reading was taken on the prepared fllms. It was necessary to walt 24 hours before taking the first read1ng. In order that the film could dry sufflolentiy to permit plaoing the rocker upon 1t. Readings were taken -very 24 hours until the film was completely dry, es shown by identical readings.

The results of the tests wore reported in Tables XVII and XVIII as the relative hardness of the I1Im every 24 hours, expressed as a peroontage of the hardness of polished plate glass. 
TABTR IVII

HARDMESS OR TALX OF BXTLRIOR HOOSE PRIMERS

Ho. 011 Series Peroent Rooker Hard. In $\%$ orery 24 Hrw. Ho. Ithoeel $24 \quad 48 \quad 72 \quad 06 \quad 120 \quad 144$

1 Soyabean

$\begin{array}{rrrrrrrr}1 & 0 & - & 1 & 1 & 2 & 2 & 3 \\ 1 & 2 & - & 1 & 2 & 3 & 3 & 3 \\ 1 & 4 & 1 & 1 & 2 & 3 & 3 & 3 \\ 1 & 6 & 1 & 1 & 2 & 3 & 3 & 3 \\ 1 & 8 & 1 & 1 & 3 & 3 & 3 & 3 \\ 1 & 10 & 1 & 2 & 3 & 3 & 3 & 3 \\ 1 & 15 & 1 & 2 & 3 & 3 & 3 & 3 \\ 1 & 20 & 1 & 2 & 3 & 3 & 3 & 3\end{array}$

S Sorabean

$\begin{array}{ll}2 & 2 \\ 2 & 4 \\ 2 & 6 \\ 2 & 8\end{array}$

13 Sogebean

38

14 Sogabean

3

3

16 Soyabean

38

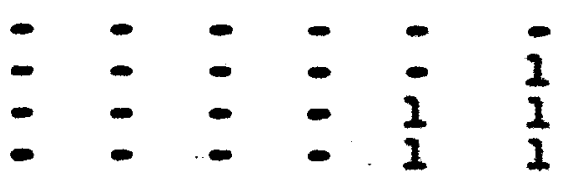

17 Linseed

18 Linseed

$4 \quad 2$

$\begin{array}{llllll}1 & 1 & 1 & 2 & 2 & 2\end{array}$

$\begin{array}{llllll}1 & 1 & 2 & 2 & 2 & 2\end{array}$

121.23

10 Linseed

20 Inseed

$\begin{array}{llllll}1 & 2 & 2 & 3 & 3 & 3\end{array}$

21 Perilla

22 Perilla

23 Por1lia

24 Perilla

50

52

54

25 Soyabean

26 Sormbean

27 Soyaboan

88 Boyabean

29 Soyabean

5

6

$\begin{array}{ll}1 & 3 \\ 2 & 3 \\ 2 & 4 \\ 8 & 4\end{array}$

$\begin{array}{llll}4 & 5 & 5 & 5 \\ 4 & 5 & 5 & 5 \\ 5 & 5 & 5 & 5 \\ 5 & 5 & 5 & 5\end{array}$

30 Soyabean

31 Soyabean

32 Sogaboan

53 LInseed

34 Par1110

6

$6 \quad 6$

66

66

6

$\begin{array}{llllll}1 & 4 & 7 & 7 & 7 & 7 \\ 3 & 5 & 7 & 8 & 9 & 9 \\ 3 & 5 & 7 & 8 & 8 & 8 \\ 3 & 5 & 7 & 8 & 9 & 9\end{array}$

$\begin{array}{rr}1 & 2 \\ 1 & 6 \\ 1 & 10 \\ 4 & 6 \\ 5 & 6\end{array}$

$\begin{array}{llllll}1 & 2 & 3 & 3 & 3 & 3 \\ 1 & 2 & 3 & 3 & 3 & 3 \\ 1 & 2 & 3 & 3 & 3 & 3 \\ 1 & 2 & 3 & 3 & 3 & 3 \\ 1 & 2 & 3 & 3 & 3 & 3\end{array}$

35 Comerotal Sample A

36 Camerelal Sample B

37 Comerolal sample $\mathrm{C}$

$\begin{array}{lllllll}2 & 1 & 2 & 3 & 3 & 3 & 3 \\ 6 & 2 & 2 & 3 & 3 & 3 & 3 \\ 0 & 1 & 2 & 2 & 2 & 3 & 3 \\ 6 & 1 & 2 & 2 & 2 & 3 & 3 \\ 6 & 2 & 2 & 3 & 3 & 4 & 4\end{array}$

Reter to Tablo III 
TABLE XVIII

HARDAESS OR TACK OF BXTERIOR ITOUSE TOPCOATS

No. 011 Serles Percent Rooker Hard. in forery $_{24}$ Hrs.

38 Soyabean

39 Soyabean

40 Sograbean

41 Soyabean

42 Soyabean

43 Soyabean

44 Soyabean

45 Soyabaan

$\begin{array}{rr}1 & 0 \\ 2 & 2 \\ 1 & 4 \\ 1 & 8 \\ 1 & 8 \\ 1 & 10 \\ 1 & 25 \\ 2 & 20\end{array}$

46 Soyabean

47 Soyaboan

48 Soyabean

49 Soraboan

$2 \quad 2$

2

2
4

2

2

b

50 Soyabean

52 Sojaboan

52 Soyaboan

53 Soyabean

3
3
3
3

2
4
8
8

54 IInseed

55

IInseed

56

Llnseed

57 ILinseed

4
4
4
4

0
2
4
6

$\begin{array}{ll}58 & \text { Peril1a } \\ 59 & \text { Peri11a } \\ 60 & \text { Perilla } \\ 61 & \text { Perilia }\end{array}$

\section{5}

5

5

5

8

$\frac{1}{4}$

56

23

$\mathbf{2}$

5

33

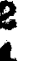

3

56

6

5

5

7

56

35

5

6

5

55

66

5

$\begin{array}{llllll}3 & 5 & 7 & 7 & 7 & 7\end{array}$

$\begin{array}{llllll}3 & 3 & 5 & 5 & 5 & 5\end{array}$

33

35

3

55

7

$\begin{array}{llll}7 & 7 & 7 & 7\end{array}$

$\begin{array}{llll}7 & 5 & 5 & 6 \\ 7 & 7 & 7 & 7\end{array}$

62 Soyabean

63 Sojabean

64 Soyabean

65 Soyabean

66 Soyaboan

$\begin{array}{ll}6 & 6 \\ 6 & 6 \\ 6 & 6 \\ 6 & 6 \\ 6 & 6\end{array}$

$\begin{array}{llllll}3 & 4 & 5 & 5 & 5 & 5 \\ 1 & 3 & 3 & 3 & 3 & 3 \\ 2 & 3 & 3 & 3 & 3 & 3 \\ 2 & 4 & 4 & 4 & 4 & 4\end{array}$

67 Comercial Sample A

B8 Comercial Sample B

69 Commercial Sample C

$\begin{array}{llllll}1 & 3 & 3 & 4 & 4 & 4 \\ 3 & 5 & 5 & 5 & 5 & 5 \\ 4 & 4 & 5 & 5 & 5 & 5 \\ 3 & 5 & 6 & 6 & 6 & 6\end{array}$

$1 \quad 2 \quad 3 \quad 3 \quad 3 \quad 3$

$\begin{array}{llllll}4 & 6 & 7 & 7 & 7 & 7\end{array}$

$\begin{array}{llllll}5 & 7 & 8 & 9 & 9 & 9\end{array}$

$\begin{array}{llllll}5 & 7 & 8 & 8 & 8 & 8\end{array}$

* Rofer to Table III 
CONCLUSIONS

A comparison of the date obtalned showed a groeter inltial set for the paints containing higher percentages of ethyl cellulose. The soyebean oil paints drled at a much slower rate than elther the linseed or perilla oils. This vas expected, however, since soyabean oll has poorer drying qualities because of the large percentage of oleic acid contained. The soyabean old palnts also produced mach softer plims when thoroughly dry than did the othar samples.

The behavior of the primers in series two was very peoullar. These samples showed practically no amount of drying other than the loss of rolatile matter. After 144 hours the films were st1ll too tacky for use of the hardness rocker.

When the primers were compared with the topcoats, it was seen that the latter dried muoh faster. Although the hardness of the Ilnseed and perilla oll topcosts, when dry, were about oqual in hardness to their respoctive primers, the soyabean ofl topcoats became much harder than their corresponding primers. In general the test samples took about the same length of time to dry but were much harder than the oomerclal paints. 
PART VIII

ABRASION RESISTANCE 
THEORETICAI

The abrasion resistance of a paint film may be defined as its ability to resist wear.

This property may be measured relatively by means of a gravity sand blast. The quantity of sand required to wear through films of equal thickness is a relative mossure of their ability to resist wear.

The apperatus conglsts essentielly of a gless tube 5 reet long having an internal bore of one inoh. The tube is supported in an upright position over the panel to be tested.

The fllms must be thoroughly ory and the test should be conducted at a constant temperature and humid1ty. Also the type of abrasive material selected should be such that it will not wear or change 1ts shape read11y. Suoh a material is ottawa sand. It 1s round, w1ll not wear readily, and has no sharp protruding surfaces. 
Instead of preparing fresh fllms for use in this test, the fllms oast provlously for the hardness determination were used. As stated before, these films had a thickness of $0.003 \pm 0.0005$ inches by aotual measuremont.

The abresivo material consisted of ottawa sand ranging in alze from 20 to 30 mesh or approximately 1 in diamoter.

The test panel was set at an angle of $45^{\circ}$ to the horlzontal and the sand allowed to drop through a funnel having a bore of 0.125 inches. Then the sand reashed the bottom of the tube, it soattered to strike a surface on the panel about one lnoh in dlameter. The sand was continually poured in until the coating had worn away, just d180losing tho glass surface benoath. The results of the tests were reported in Tables XIX and $X X$ as the pounds of send required to wear through a known thickness of fllm. These values were taken as a measure of the abrasion resistance of the paints. 
TARE XIX

ABRASION RESISTANCE OF EXTERIOR HOUSE PRIMERS

\begin{tabular}{|c|c|c|c|c|}
\hline Ho. & 011 & $\begin{array}{l}\text { Serles } \\
\text { No. }\end{array}$ & $\begin{array}{l}\text { Pexcent } \\
\text { Ithooel }\end{array}$ & $\begin{array}{l}\text { Abresion Resistance } \\
\text { Pounds or Sand }\end{array}$ \\
\hline $\begin{array}{l}1 \\
2 \\
3 \\
4\end{array}$ & $\begin{array}{l}\text { Soyabean } \\
\text { Soyabean } \\
\text { Soyabean } \\
\text { Sojabean }\end{array}$ & $\begin{array}{l}\frac{1}{2} \\
\frac{1}{1}\end{array}$ & $\begin{array}{l}0 \\
2 \\
4 \\
6\end{array}$ & $\begin{array}{l}54 \\
67 \\
73 \\
48\end{array}$ \\
\hline $\begin{array}{l}17 \\
18 \\
19 \\
20\end{array}$ & $\begin{array}{l}\text { Inseed } \\
\text { IInseed } \\
\text { IInseed } \\
\text { IInseed }\end{array}$ & $\begin{array}{l}4 \\
4 \\
4 \\
4\end{array}$ & $\begin{array}{l}0 \\
2 \\
4 \\
6\end{array}$ & $\begin{array}{r}86 \\
89 \\
100 \\
95\end{array}$ \\
\hline $\begin{array}{l}21 \\
22 \\
23 \\
24\end{array}$ & $\begin{array}{l}\text { Perilia } \\
\text { Peri11a } \\
\text { Peri12a } \\
\text { Peri1la }\end{array}$ & $\begin{array}{l}5 \\
5 \\
5 \\
5\end{array}$ & $\begin{array}{l}0 \\
2 \\
4 \\
6\end{array}$ & $\begin{array}{l}40 \\
48 \\
36 \\
31\end{array}$ \\
\hline $\begin{array}{l}35 \\
36 \\
87\end{array}$ & $\begin{array}{l}\text { Combercia } \\
\text { Commerola } \\
\text { Commercia }\end{array}$ & $\begin{array}{l}1 \text { Sample } \\
1 \text { Sanple } \\
1 \text { Sample }\end{array}$ & $\begin{array}{l}\mathbf{A} \\
\mathrm{C}\end{array}$ & $\begin{array}{l}12 \\
22 \\
38\end{array}$ \\
\hline
\end{tabular}




\section{TABLE XX}

ABRASION RESISTAHCE OF EXTERIOR HOUSE TOPCOATS

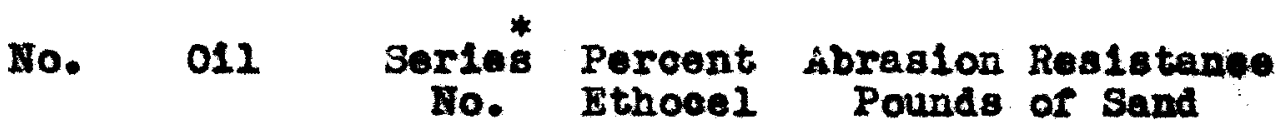

\begin{tabular}{|c|c|c|c|}
\hline $\begin{array}{l}38 \\
38 \\
40 \\
41\end{array}$ & $\begin{array}{l}\text { Soyabean } \\
\text { Soyabean } \\
\text { Soyabean } \\
\text { Soyabean }\end{array}$ & $\begin{array}{l}1 \\
1 \\
1 \\
1\end{array}$ & $\begin{array}{l}0 \\
2 \\
4 \\
6\end{array}$ \\
\hline $\begin{array}{l}54 \\
55 \\
56 \\
57\end{array}$ & $\begin{array}{l}\text { Linseed } \\
\text { Linseed } \\
\text { Inseed } \\
\text { Inseed }\end{array}$ & $\begin{array}{l}4 \\
4 \\
4 \\
4\end{array}$ & $\begin{array}{l}0 \\
2 \\
4 \\
6\end{array}$ \\
\hline $\begin{array}{l}58 \\
58 \\
60 \\
61\end{array}$ & $\begin{array}{l}\text { Perilla } \\
\text { Per 111a } \\
\text { Perilia } \\
\text { Per } 111 a\end{array}$ & $\begin{array}{l}5 \\
5 \\
5 \\
5\end{array}$ & $\begin{array}{l}0 \\
2 \\
4 \\
6\end{array}$ \\
\hline $\begin{array}{l}67 \\
68 \\
69\end{array}$ & $\begin{array}{l}\text { Commerclal } \\
\text { Comere } \\
\text { Cammerelal }\end{array}$ & $\begin{array}{l}\text { Sample A } \\
\text { Sample B } \\
\text { Sample C }\end{array}$ & \\
\hline
\end{tabular}


CONCLUSIONS

The results of the abrasion tests showed a remarkable degree of toughness on the fart of those flins contalning higher percentages of ethyl collulose, although in practioally all asses this toughness apparontly deoressed when the percent of the cellulose derivative reached approximately $4 \%$ to $6 \%$. The only explanation for this bohavior is that the othyl oellulose may here been excessively degraded because of the longer time required to oook the higher percentages. Also the drying effect may heve increased in proportion to the increase in toughness. It is to be noted that as the films became tougher they became more flexible and less hard, thus ylolding higher values. This was substantiated in part by the rooker hardness or these films.

It was also erident thet the linseed and porilla olle formed harder films than the soyabean oll beouse of the high percentage of oleic acld in the latter.

In general the test samples showed that the primers were softer and more flexible than the topoota while in the case of the oomercial peints this relation was reversed. A possible explanation was the variation In the vehicle formulations. 
85.

PART IX

VEATERABILITY 


\section{THEORETICAL}

The purpose of weathering or exposure tests is to obtain information on the durability of paint produots Intended for protective couting.

There are a large number of variables whioh enter Into the testing of palnts or a small scale, and it is doubtful whether the results thus obtalned can be applied directly to the durability of the same costings on large structures.

Faotors (1) which have an erfect upon the durability of coatings in relation to exposure tests are listed below:

1. Wothod of preparation.

2. Agine paint.

3. Drying period between coats.

4. Indoor preparation.

5. eging of fresh film before exposure.

6. Type of wood.

7. Ropeinting.

8. Painting of panel back.

9. Paint applioation.

10. Color

11. Time of exposure.

12. "eather Immediately after exposure.

13. CIlmate. 
14. Atmospheric conditions.

15. Angle of exposure.

16. Loisture.

17. Size of panel limitation.

18. cooloration.

18. Personal equation.

These ractors are more or less dependent upon

ono anothor and may oither be detrimental or benerioial to the coating as far as results are concerned. 
EXPERIMENTAL ORK

Southern Yellow zine was selocted as a test surface because of the known effect of pretective contInga to deterlorate more rapldiy on 1 than on other types of wood.

The panels used were of Ifrst grade stook and had a test surface of 6 by 24 inches or 84 square inches. The backs and edges of the test panels were sealed with two coets of aluminum paint. The test surfoce was sanded with two grades or papor in proparation for coating. The primers were epplied with 2 lnoh brush and allowed to dry for a perlod of one weok. In applyIng the paint to the surface, the panels were painted first along the length from top to bottom and from left to right. This was followed by an application at right angles to the first from bottom to top and from right to loft. In this way a uniform coating was obtained on the test surface. The topooats were applied similarly. A sumation of the panela prepared for exposure data is given in Table XXI. The penels were exposed (Fig. 5) at $45^{\circ}$ to the South on Waroh $6,1939$. Because of the short time the panels have been exposed no definite rallure has taken place, the test surfaces being in perfect oondition. 
TABLE XXI

SUMAKRY OF PATELS PREPARTD YOR FEATEFING

Panel Primer 011 Sarles Percent Topooat o11 Berlế Porcent No. No. Ho. Ethocel Ho. Ho. Ethooel

\begin{tabular}{|c|c|c|c|c|c|c|}
\hline $\begin{array}{r}1 \\
1 \\
2 \\
2 \\
3 \\
3 \\
4 \\
4 \\
5 \\
5 \\
6 \\
6 \\
7 \\
29 \\
8 \\
1 \\
1 \\
1 \\
1 \\
1 \\
2 \\
5 \\
4 \\
5 \\
6 \\
1 \\
2 \\
3 \\
4 \\
5 \\
6 \\
1 \\
2 \\
3 \\
4 \\
5 \\
6 \\
9 \\
10\end{array}$ & 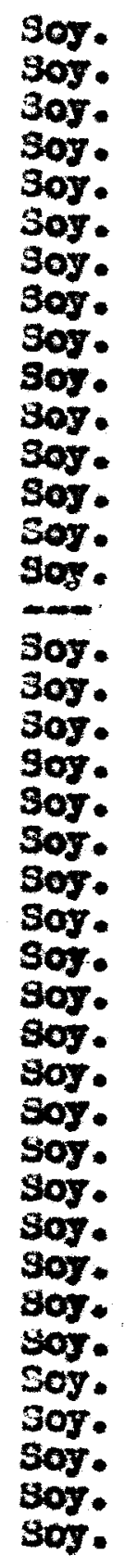 & \multicolumn{2}{|c|}{$\begin{array}{rr}1 & 0 \\
1 & 0 \\
1 & 8 \\
1 & 2 \\
1 & 4 \\
1 & 4 \\
1 & 4 \\
1 & 6 \\
1 & 6 \\
1 & 8 \\
1 & 8 \\
1 & 8 \\
1 & 10 \\
1 & 10 \\
1 & 15 \\
8 & 6 \\
1 & 20 \\
1 & 5 \\
1 & 0 \\
1 & 0 \\
1 & 0 \\
1 & 0 \\
1 & 0 \\
1 & 2 \\
1 & 8 \\
1 & 4 \\
1 & 8 \\
1 & 8 \\
1 & 10 \\
1 & 0 \\
1 & 0 \\
1 & 2 \\
1 & 4 \\
1 & 6 \\
1 & 8 \\
1 & 1 \\
1 & 10 \\
1 & 0 \\
1 & 2 \\
1 & 2 \\
1 & 4 \\
1 & 6 \\
1 & 8 \\
1 & 10 \\
2 & 2 \\
2 & 4\end{array}$} & $\begin{array}{l}38 \\
54 \\
39 \\
54 \\
40 \\
54 \\
11 \\
54 \\
42 \\
54 \\
45 \\
54 \\
46 \\
68 \\
45 \\
39 \\
40 \\
41 \\
12 \\
57 \\
57 \\
57 \\
57 \\
57 \\
57 \\
58 \\
58 \\
58 \\
58 \\
58 \\
58 \\
61 \\
61 \\
61 \\
61 \\
61 \\
61 \\
46 \\
47\end{array}$ & $\begin{array}{l}\text { Soy. } \\
\text { Lin. } \\
\text { Soy. } \\
\text { LIn. } \\
\text { Soy. } \\
\text { Lin. } \\
\text { Soj. } \\
\text { Lin. } \\
\text { Soy. } \\
\text { Lin. } \\
\text { Soy. } \\
\text { Lin. } \\
\text { Soy. } \\
\text { Soy. } \\
\text { Soy. } \\
\text { Soy. } \\
\text { Soy. } \\
\text { Soy. } \\
\text { Soy. } \\
\text { Lin. } \\
\text { Lin. } \\
\text { Inn. } \\
\text { Lin. } \\
\text { Lin. } \\
\text { Lin. } \\
\text { Por. } \\
\text { Per. } \\
\text { Por. } \\
\text { Per. } \\
\text { Per. } \\
\text { Per. } \\
\text { Per. } \\
\text { Por. } \\
\text { Per. } \\
\text { Por. } \\
\text { Per. } \\
\text { Por. } \\
\text { Soy. } \\
\text { Soy. }\end{array}$ & $\begin{array}{l}1 \\
4 \\
1 \\
4 \\
1 \\
1 \\
4 \\
1 \\
4 \\
2 \\
4 \\
1 \\
6 \\
1 \\
5 \\
1 \\
1 \\
1 \\
1 \\
4 \\
4 \\
4 \\
4 \\
4 \\
4 \\
5 \\
5 \\
5 \\
5 \\
5 \\
5 \\
5 \\
5 \\
5 \\
5 \\
5 \\
5 \\
2 \\
8\end{array}$ \\
\hline
\end{tabular}

* Refer to Trbie III 
TABLE DXI

ConTrnusD

SUMAARY OF PANGIS PRRPARED TOR MRATHERTIY

Panel Primor 011 series Pereent Topocat 011 series Paroent Ho. Ho. Ho. Bthooel Ho. Ho. Bthoeel

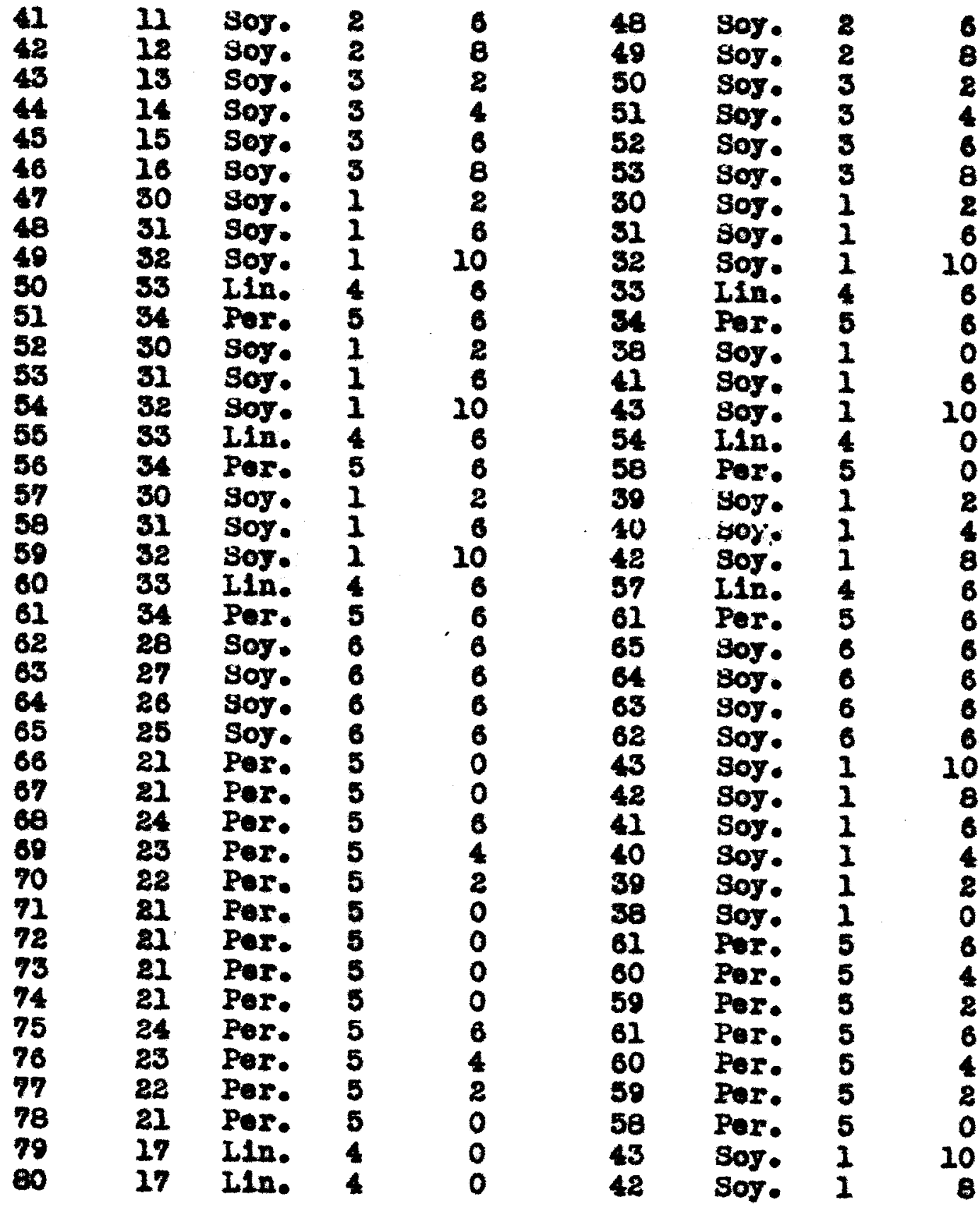

* Refar to Tabla III 
TAPLE 001

COTTINUED

SJIntaRY OP PABRLS PREPARED TOR VRATHERTNG

Panel Primer 011 Serie* Peroent Topooat 011 serles Peroent Ho. No. Ho. Ithooel Ho. Ho. Bthooel

\begin{tabular}{|c|c|c|c|c|c|c|}
\hline $\begin{array}{l}81 \\
88 \\
83 \\
84 \\
85 \\
86 \\
87 \\
88 \\
89 \\
90 \\
99\end{array}$ & $\begin{array}{l}20 \\
29 \\
18 \\
17 \\
17 \\
17 \\
17 \\
20 \\
19 \\
18 \\
17\end{array}$ & 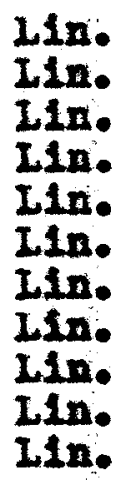 & $\begin{array}{l}4 \\
4 \\
4 \\
4 \\
4 \\
4 \\
4 \\
4 \\
4\end{array}$ & $\begin{array}{l}6 \\
4 \\
2 \\
0 \\
0 \\
0 \\
0 \\
6 \\
4 \\
2 \\
0\end{array}$ & $\begin{array}{l}41 \\
40 \\
39 \\
38 \\
57 \\
56 \\
55 \\
57 \\
56 \\
55 \\
54\end{array}$ & $\begin{array}{l}\text { Soy. } \\
\text { Soj. } \\
\text { SoJ. } \\
\text { Soy. } \\
\text { IIn. } \\
\text { Iin. } \\
\text { IIn. } \\
\text { Lin. } \\
\text { Lin. } \\
\text { Lin. } \\
\text { Lin. }\end{array}$ \\
\hline
\end{tabular}

* Harer to Table III 


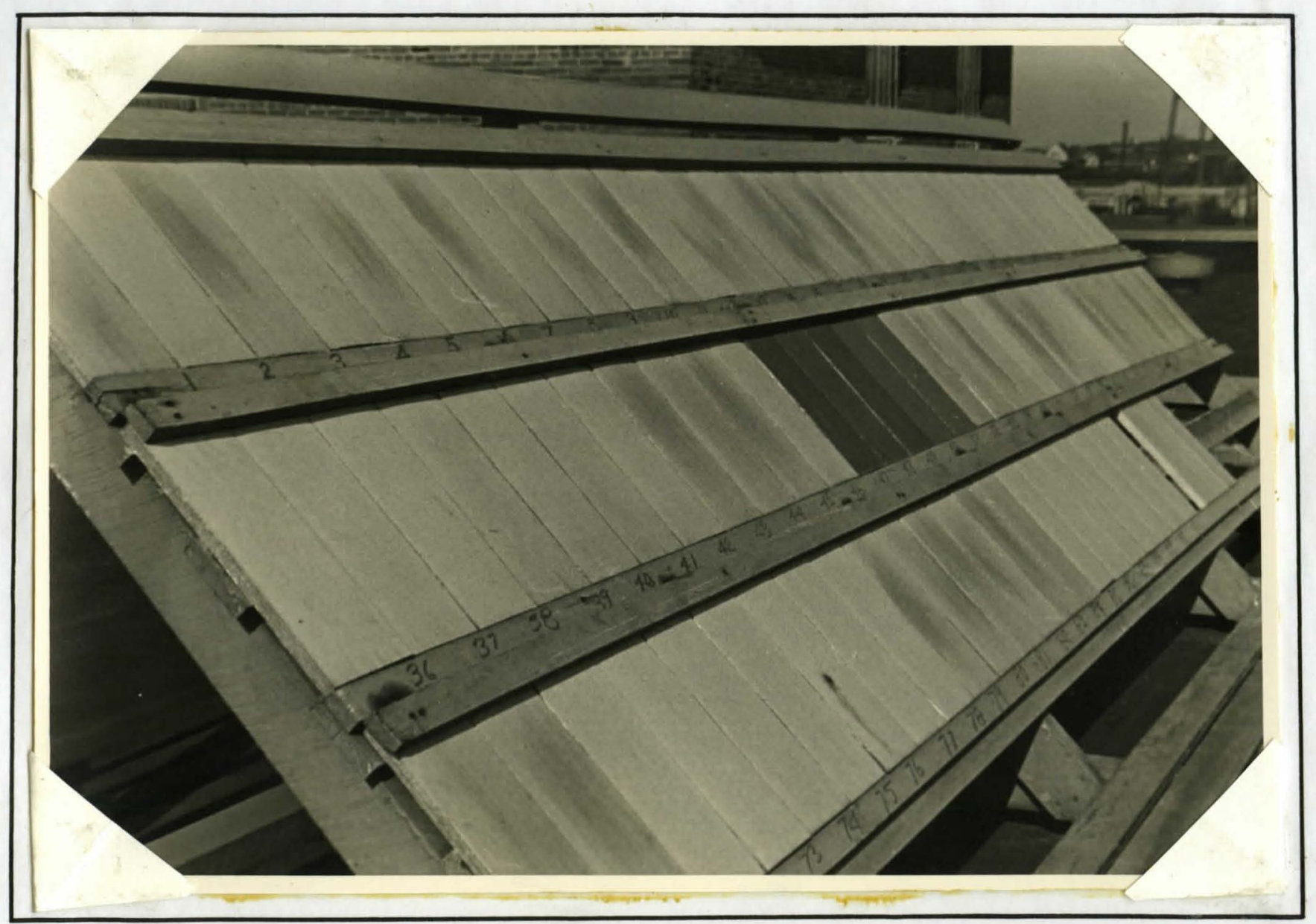

Figure 5

Paint Fence 
03.

SUMAARY 
A sumary of the results obtained in this Inrestigation is stated as follows:

1. The introduction of ethyl cellulose in drying olls for use in exterior house paints produced a greater initial set or faster dryine timo but not in proportion to its increase in concontration.

2. Ethyl cellulose Imparted an Inoreasing degreo of toughness or flexiblilty up to a certain concentration where it seeped to loose effect.

3. Ethyl cellulose definitely decreased the penetration of wood primers, although high percentages of the aerivative did not produce a proportional decrease in penetration.

4. The bloling power was decreased as the ooncentration of the thyl cellulose was increased.

5. The leveling as well as the brushablifty was increased to some extent by reiaing the ethyl cellulose content.

6. Ethyl cellulose had little effect upon the gloss or sagging properties of exterior paints.

7. The nethod of incorporation of the derivative In a drying oil is important from the standpolnt of the results produced by the oll when used as rehiole in painte. 
8. The offects produced on different oils were found to be praotically the same. A small amount of the derivative seomed to have such offeot a larger quantities. Although - thy 1 oellulose did not produce any dotrinontal erfoots, the magnitude of the benerfolal erfects produced in the exterior paints wore not considerable. However, the incorporation of this cerivative in arying o1l is a most convenlent and useful method for bodying the oll. Before proceeding further an economio consideration of this problem should be undertaken. 
96.

ACROWLEDCRMATS 
This investigation was made possible by a fellowahlp sponsored by the Dow Chemioal Co. of Mlaland. Mlohigan. The author wiahes to express his alnoere thanks and approolation to the Dow Chemical Co. for making this followshlp arallable and to Mr. W.R. Collings and ur. J.I. Sherk of the Cellulose and Plastlos Diviaion for auggesting and outilning this problem and for the raluable suggestlons and guldance that have been rondered.

The author wlahes to thank the rollowing porsone for thelr valuable suggestlons concerning work involved in this investigation.

ur. Otto Mileti of the Chas. R. Long. Jr. Co. Dr. J.S. Lang of the Deron a Rayrolde Co. Mr. E.L. Beakes of the Ky. Color a Ches. Co. Tho autinor also wimes to thank J. Harold Rose for his oapable and willing assistanos in the oxperlmontal work involred in this investigation. 
98.

BIBLIOGRAPHY 
(1) G.W. Ashman; Ind. Bng. Chem., 28, 934, (1936).

(2) F.L. Browne; Ind. Bng. Chem,, 26, 369, (1934).

(3) H.A. Cardnor; "The Chemical and Physloal Examination of Paints, Varnishes, Lacquers, And Colors". 7 th Edition, Institute of Paint and Varnish Researoh, Washing, D.C., (2935).

(4) J.S. Long; Paint \& Var. Prod. Mge., 35, 5, Fob. (1930).

(5) G.H. P1ckard; Paint \& Var. Prod. Mgr., 5, 12, yerch (1931).

(6) D.W. Robertson; "House Paint Primers and Undercoatera", Publication of Titariun Plement Corp., Hew York, H.Y., (2936).

(7) D.W. Robertson; "House Paint Primers in Relation to Topcoat Formulation". Publioation of Titanium PIgment Corp., New York, N.T., (2936).

(B) J.M. Sohantz; Paint \& Var. Prod. Ugr., 12, 32, June (1935).

(0) J.I. Sherk and N.R. Poterson; "The Effeot of Ethyl Cellulose on Vernishes and Drying 01ls", Bulletin of the Dow Chemical Co., Mlaland, Mioh.. Cellulose and Plastics Laboratory, (1938).

(10) Maximilian Tooh; "The Chemiatry and Teohnology of Paints", D. Van Nostrand Co., New York, N.Y., (1916). 
(12) E.E. Ware; Ind. Hng. Chem., 28, 903, (1936).

(12) Hans Wolff; Palnt var. Prod. Mgr., 16, 12, Jan. (1837).

(13) Aluminum Company of Amorlce, Plttsburgh, Penn.. Publication "Aluminum Paint Manual". Bulletin No. AD 123 8-37; 30M, (1937).

(14) Dow Chemioel Co., Kidlend, Mloh., Fublication "athocel". Bulletin No. 2, (1837).

(15) Dow Chemicel Co., vidlend, Mieh.. Bulletin "Drylng 011 s and Ethocel". Cellulose and Plastics Laboratory. (1937).

(16) Hoath and MIIIIgan MAg. Co., Ohloago, Ill., Bullet1s "History of Falnts, Pigments, and Colors From Romote Ages". (1897).

(17) Hew Jereeg Zinc Co., How York, N.Y., Publication "Zine P1gments", Nor. (1936).

(18) Nuodex Products Ino., Elizabeth, N.J., Publication Wuodex Technical Bulletins". Bulletin No. 1 . (2934).

(19) TItanlum Plgment Corp.. New York, N.Y.. Publication "T1tanox Plgments". Bulletin No. 6-37 Con. (1936). 